\title{
Decontaminating N95 and SN95 masks with Ultraviolet Germicidal Irradiation (UVGI) does not impair mask efficacy and safety: A Systematic Review
}

Katie O’Hearn ${ }^{1}$; Shira Gertsman ${ }^{1}$; Margaret Sampson² ${ }^{2}$ Richard Webster ${ }^{3}$; Anne Tsampalieros ${ }^{3}$;

Rhiannon $\mathrm{Ng}^{1}$; Jess Gibson ${ }^{1}$; Anna-Theresa Lobos ${ }^{4}$; Nina Acharya ${ }^{5}$; Anirudh Agarwal ${ }^{6}$;

Samantha Boggs ${ }^{4}$; Graham Chamberlain ${ }^{4}$; Emiliyan Staykov ${ }^{7}$; Lindsey Sikora ${ }^{8}$; and James Dayre McNally ${ }^{1,4}$

${ }^{1}$ Children's Hospital of Eastern Ontario Research Institute, Ottawa, Ontario, Canada

${ }^{2}$ Library Services, Children's Hospital of Eastern Ontario, Ottawa, Ontario, Canada

${ }^{3}$ Clinical Research Unit, Children's Hospital of Eastern Ontario, Ottawa, Ontario, Canada

${ }^{4}$ Department of Pediatrics, Children's Hospital of Eastern Ontario, Ottawa, Ontario, Canada

${ }^{5}$ Michael G. DeGroote School of Medicine, McMaster University

${ }^{6}$ Max Rady College of Medicine, University of Manitoba, Winnipeg, Manitoba, Canada

${ }^{7}$ Department of Biology, University of Ottawa, Ottawa, Ontario, Canada

${ }^{8}$ Health Sciences Library, University of Ottawa, Ottawa, Ontario, Canada

\section{Corresponding author:}

James Dayre McNally

401 Smyth Road, Ottawa, Ontario, Canada, K1H 8L1

Phone: 613-737-7600 ext. 3553

Fax: 613-738-4287

E-mail: $\underline{\text { dmcnally@cheo.on.ca }}$ 
Running Title: Decontaminating N95 masks with UVGI 


\begin{abstract}
Background: Inadequate supply of filtering facepiece respirators (FFR) for healthcare workers during a global pandemic such as the novel coronavirus outbreak (SARS-CoV-2) is a serious public health issue.
\end{abstract}

Aim: To synthesize existing data on the effectiveness of ultraviolet germicidal irradiation (UVGI) on N95 FFR decontamination.

Methods: Systematic review (PROSPERO CRD42020176156) on UVGI in N95 FFRs using Embase, Medline, Global Health, Google Scholar, WHO feed, and MedRxiv. Two reviewers independently determined eligibility and extracted predefined variables. Original research reporting on function, decontamination, or mask fit following UVGI were included.

Findings and Conclusions: Thirteen studies were identified, comprising 54 UVGI intervention arms and 58 N95 FFR models. FFRs consistently maintained certification standards following UVGI. Aerosol penetration averaged $1.19 \%(0.70-2.48 \%)$ and $1.14 \%(0.57-2.63 \%)$ for control and UVGI arms respectively. Airflow resistance for the control arms averaged $9.79 \mathrm{~mm}_{2} \mathrm{O}$ (7.97-11.70 mm $\left.\mathrm{H}_{2} \mathrm{O}\right)$ vs $9.85 \mathrm{~mm} \mathrm{H}_{2} \mathrm{O}\left(8.33-11.44 \mathrm{~mm} \mathrm{H}_{2} \mathrm{O}\right)$ for UVGI arms. UVGI protocols employing a cumulative dose $>20,000 \mathrm{~J} / \mathrm{m}^{2}$ resulted in a $2 \log$ reduction in viral load. A $>3 \log$ reduction was observed in 7 UVIG arms using $>40,000 \mathrm{~J} / \mathrm{m}^{2}$. Impact of UVIG on fit was evaluated in two studies $\left(16,200 ; 32,400 \mathrm{~J} / \mathrm{m}^{2}\right)$ and did not find evidence of compromise. Our findings suggest that further work in this area (or translation to a clinical setting) should use a cumulative UV-C dose of $40,000 \mathrm{~J} / \mathrm{m}^{2}$ or greater, and confirm appropriate mask fit following decontamination.

Keywords: PPE, Decontamination, Masks, N95, UVGI 


\section{Introduction}

The global spread of the novel coronavirus (SARS-CoV-2) threatens public health worldwide, and healthcare professionals are at an increased risk due to their close contact with infected patients. Physicians have reported that NIOSH-certified N95 filtering face respirators (FFRs), which filter 95\% of airborne particles[1], were the personal protective equipment (PPE) that they felt protected them most during the last serious coronavirus outbreak in 2003 (SARSCoV-1)[2]. Correspondingly, N95 FFRs are currently recommended by the U.S. Centers for Disease Control and Prevention (CDC) to be donned by healthcare professionals treating patients with the coronavirus disease (COVID-19)[3]. Unfortunately, PPE shortages are characteristic of large epidemics, and COVID-19 is no exception[4,5]. Consequently, rationing FFR supply has become a matter of increasing urgency at many hospitals worldwide.

A potential approach to extending the use of existing FFRs would be to decontaminate and re-use the masks. This has prompted the question of whether FFRs can be safely decontaminated for reuse without compromising their structural integrity and efficacy[6]. Previously studied FFR decontamination methods have included bleach, ethanol, hydrogen peroxide, autoclaving, microwaving, and UV light[7-9]. Ultraviolet germicidal irradiation (UVGI) using shortwave ultraviolet-C light (UV-C, usually $245 \mathrm{~nm}$ ) has a long history of antiseptic applications in medicine and is used for air disinfection in hospitals[10]. Recent reviews highlight the growing popularity of UV-C light for microbial decontamination of objects from toothbrushes to stethoscopes[11-13], and its scalable nat ${ }^{1}$ ure makes it suitable for largescale decontamination during a pandemic. However, any decontamination process may limit the

\footnotetext{
${ }^{1}$ Abbreviations: CDC - Centres for Disease Control; FF - Fit factor; FFR - Filtering facepiece respirator; MDIFF10 Multi donning fit factor; NIOSH - National Institute for Occupational Safety and Health; OSHA - Occupational Safety and Health Administration; PPE - personal protective equipment; PRISMA - Preferred Reporting Items for Systematic Reviews and Meta-Analyses; UV-C - ultraviolet light; UVGI - Ultraviolet germicidal irradiation
} 
functionality of the mask if it alters its fit, filter efficiency (aerosol penetration), and/or airflow resistance[14]. Therefore, while some institutions have already implemented UVGI FFRdecontamination protocols during the COVID-19 pandemic[15], FFR producers continue to recommend disposal of contaminated FFRs due to the lack of an evidence-based protocol that addresses these important functional parameters[16].

To help inform FFR-reuse policies and procedures, our team has conducted three systematic reviews to synthesize existing published data regarding the effectiveness of UVGI, heat, microwave irradiation, and chemical disinfectants for N95 FFR decontamination This review will focus on UVGI, with the following objectives: (1) to assess the impact of the UVGI method on FFR performance, with a specific focus on aerosol penetration and airflow resistance; (2) to determine the effectiveness of the UVGI decontamination method at removing viral or bacterial load; and (3) to describe measures or observations related to fit or physical degradation.

\section{Methods}

Study protocol and objectives were established a priori and registered on PROSPERO on $25^{\text {th }}$ March 2020 (CRD42020176156), and reported here according to the PRISMA guidelines of systematic reviews (Appendix A)[17]. The protocol was also uploaded as a pre-print to OSF on $29^{\text {th }}$ March 2020 (https://osf.io/238yh/).

\section{Eligibility Criteria}

Studies were eligible for inclusion in this systematic review if they satisfied all of the following criteria: (1) Original publication or systematic review; (2) Study reported on decontamination procedures for N95 (including SN95) filtering facemask respirators or their 
components; (3) At least one of the decontamination procedures evaluated used ultraviolet light; and (4) The study reported on at least one of the following outcomes of interest: (i) effectiveness of the UVGI method at removing viral or bacterial load; (ii) impact of the UVGI method on filtering face mask performance, with a specific focus on aerosol penetration and airflow resistance (pressure drop); or (iii) measures or observations related to change in mask fit or physical degradation of the mask following UVGI exposure. Only studies published in English or French were included. Studies published prior to 1972, the year that the N95 FFR was invented, were excluded. We also excluded editorials, narrative reviews, book chapters and patents.

\section{Search and Selection}

The following databases were searched by two health sciences librarians (LS and MS) during the electronic component of the systematic review: Medline (1946- March 22, 2020) and Embase (1947-March 22, 2020) through the Ovid interface and Global Health (1913-March 20, 2020) via CAB Direct. A search strategy was developed in Medline, reviewed and then translated into the other databases (Appendix B). There were no language exclusion criteria, nor any other publication restrictions. Google Scholar was searched (March 24, 2020). The COVID19 search concept was adapted from search developed by Wichor Bramer and posted on Search blocks/Zoekblokken (https://blocks.bmi-online.nl/catalog/397, visited March 18, 2020). This yielded 2960 hits. The first 1000 were harvested using Publish and Perish and records were reviewed in order of relevance until a series 50 consecutive apparently irrelevant records was reached. This generated a set of 208 records, which was then exported to EndNote. The World Health Organization (WHO) COVID-19 record set posted March 23, 2020 was downloaded from https://www.who.int/emergencies/diseases/novel-coronavirus-2019/global-research-on-novel- 
coronavirus-2019-ncov. The records were imported into Reference Manager, where topical queries were performed. References from all searches were then entered into an Endnote file and duplicate records were removed.

\section{Citation screening and data extraction}

Titles and abstracts were then uploaded to InsightScope (www.insightscope.ca) for title and abstract screening and full text review. At both title/abstract and full text review, citations were assessed in duplicate and independently. To allow for rapid completion of the systematic review task, the assessments were performed by a team of 13 reviewers recruited from the University of Ottawa, University of Manitoba and McMaster University. Each reviewer was asked to read the protocol and complete a qualification or test set of size 50 citations ( 6 true positives, 44 true negatives), and were required to achieve a sensitivity in excess of $80 \%$. Of the reviewers eight $(62 \%)$ correctly identified all 6 true positives, with the remaining $5(38 \%)$ correctly identifying 5. At both title/abstract and full text review, records were removed only if both reviewers agreed it to exclude. Those cases with conflicts were resolved by review by the study lead (JDM) or co-investigator (KO). At the completion of full text review the study lead reviewed the eligible citations to identify potential duplicates and confirm eligibility. A data extraction tool was developed in REDCap[18,19] by the study lead (JDM) and piloted by coinvestigator (KO) on five eligible studies. Eligible studies were divided equally among the reviewers for duplicate, independent data extraction, followed by conflict resolution by a third co-investigator (JDM, KO).

Outcome data is reported for N95 (particulate or surgical) masks or their components only. Other N95 masks (e.g. R or P) were not included in the analysis. "Components" was defined as a piece of an N95 mask that had been cut out with all layers still intact. When 
investigators separated out the layers of an N95 mask and reported outcomes for each individual layer, this data was not included in the analysis but was reported descriptively in the results. When authors did not report the UV-C dose, but reported intensity and time, UV-C dose was calculated. Preference was always given to the actual UV-C dose administered versus the target UV-C dose. In cases where authors only reported the target dose, but did report the intensity and time administered, administered UV-C dose was calculated. For ease of reporting, all doses were converted to $\mathrm{J} / \mathrm{m}^{2}$. When necessary, data was extracted from figures using SourceForge Plot Digitizer (http://plotdigitizer.sourceforge.net/ ).

\section{Study analysis and Statistics}

All statistical analysis were performed using the R statistical programming language[20]. Data was meta-analyzed using a random effects model with the R package 'meta'[21]. Random effects meta-analysis were employed to present either the pooled absolute value pre / post UVGI or relative change (from control or no treatment arm).

For both the particle penetration and airflow resistance outcomes the data was presented as an absolute value. Appropriateness of pooling was assessed by examining studies heterogeneity using an $\mathrm{I}^{2}$ statistic. Lindsey et al[22] had one more than one UVGI intervention arm and out of concern that this one experimental paradigm might contribute disproportionately to our data and to reduce within study variation, we took a conservative approach of only including this study's highest dose experiment. For the outcome UVGI decontamination, all but one study was on viruses; to improve comparability the one study on bacteria decontamination was removed. Significant heterogeneity was seen with the methods and outcomes related to contamination and decontamination. To account for differences in methods (viral load, application and retrieval from mask) we reported pooled results using log change. For studies 
which did not report log change, values were calculated based on the data provided. The average log change was taken across mask types within the same dose and medium. (in addition to absolute value or change). For the viral load log change, standard error was missing in $20 \%$ of study arms. To minimise bias, we imputed standard error for these cases, by substituting the average standard error of all study arms (NB: modeling the missing data was disregarded due to poor predictability). Again, prior to pooling the results we performed a test of statistical heterogeneity using I ${ }^{2}$ tests. Random effects meta-analysis was used. In the evaluation of UVGI and germicidal activity we also characterised the influence cumulative dose of UV light (Joules per $\left.\mathrm{m}^{2}\left(\mathrm{~J} / \mathrm{m}^{2}\right)\right)$

Risk of Bias and Quality Assessment

Risk of bias was ascertained at the study level. The following factors were determined $a$ priori as supportive of low risk of bias: (1) Application of UVGI procedures to masks from the same lot to minimize lot-to-lot variation; (2) Controlled study or pre/post study design; (3) Application of identical study procedures between arms other than intervention; and (4) Outcome evaluators blinded to study arm or outcome evaluated objectively (result provided by a machine). Based on the anticipated small size of the available literature ( $<10$ studies) and limited variability in study sample sizes generally observed in laboratory studies, no statistical test of publication bias was planned. The cumulative body of evidence regarding the application of UVGI for decontamination and reuse of FFR was evaluated using the following criteria: (1) UVGI was shown to: (1) achieve established thresholds for success for pathogen decontamination ( $\geq 2 \log$ reduction) and function (National Institute for Occupational Safety and Health (NIOSH) standards for airflow resistance and aerosol penetration); (2) these findings were demonstrated consistently ( $\geq 2$ studies); (3) without failing in any other study. 


\section{Results}

\section{Identification of Eligible Studies}

In total, 1326 records were identified through the initial database search, resulting in 1108 records for screening following de-duplication in Endnote. Title and abstract screening excluded 1053, with the review team achieving a kappa of 0.5 . At full text level the reviewers excluded 40 of the records, with a kappa of 0.95 . Review of the 15 remaining records by the study lead identified two as duplicates, and two records, a thesis and a government report, that were different reports of the same studies. Of the remaining 11, one study (Jinadatha, 2015)[23] was deemed ineligible during data extraction as only the plastic portion of the facemask was used in the evaluation of UVGI decontamination, and neither of the other two outcomes (aerosol penetration, airflow resistance) were considered. Three additional eligible studies were identified on review of the references lists of the retained studies. An overview of the search process, results and reason for exclusions are shown in the PRISMA diagram (Figure 1).

\section{Study Demographics}

Geographically, 12 studies were performed in the United States, with the remaining publication originating from East Asia. The studies included 54 total UVGI arms, with a range of 1 to 22 arms per study. A summary of the included studies is provided in Table I. The studies included a total of 58 N95 masks (average 4.5) with a range of 1 to 15 evaluated per study. The most common N95 mask types were 3M $1860(n=5), 3 M 1870(n=5)$ and 3M $8210(n=3)$. In four studies, representing 13 of the 58 masks, the N95 brand was not specified[7,9,24,25].Table I shows the masks evaluated in each study. The number of studies evaluating the 4 main study 
outcomes were: particle penetration $(n=5)$, airflow resistance $(n=3)$, germicidal activity $(n=7)$ and impact on physical characteristics/fit $(n=6)$.

\section{Particle Penetration and airflow resistance}

There were five studies identified that evaluated particle penetration post UVGI[9,22,2426] (Table II). Four of the studies evaluated a single UVGI protocol, with Lindsley et al[22] having 5 UVGI intervention arms. The particle penetration in masks were on average $1.19 \% \%$ (ranging from $0.70-2.48 \%$ ) and $1.14 \%$ (ranging from $0.57-2.63 \%$ ) for the control and post UVGI treatment arms, respectively. None of the individual studies average mean difference post UVGI treatment were statistically discernable from zero (Figure 2). Further the random effects metaanalysis (that weights the evidence by the size of the study) calculated a mean difference of 0.09\% (95\% CI -0.21-0.04; Figure 2). Statistical heterogeneity was low with an I-squared of $\sim 0 \%$. Fisher et al reported aerosol penetration for the individual layers of 6 N95 FFR models[27]. The filter efficiency of the individual filtering layers examined ranged from 87.2 to $99.5 \%$ following UVGI. The majority of filter layers had an efficiency of $>94 \%$.

Three studies evaluated airflow resistance [22,24,25] (Table III). Two of the studies evaluated a single UVGI protocol, with Lindsley et al evaluating 5 UVGI intervention arms (NB: only the highest dose arm was included in our meta-analysis). The airflow resistance in masks were on average $9.79 \mathrm{~mm} \mathrm{H}_{2} \mathrm{O}$ (ranging from 7.97-11.70 $\mathrm{mm} \mathrm{H}_{2} \mathrm{O}$ ) and $9.85 \mathrm{~mm} \mathrm{H}_{2} \mathrm{O}$ (ranging from 8.33-11.44 $\mathrm{mm} \mathrm{H}_{2} \mathrm{O}$ ) for the control and post UVGI treatment arms, respectively. None of the individual studies average mean difference post UVGI treatment were statistically discernable from zero (Figure 2). The random-effects meta-analysis calculated a mean difference of $0.03 \%$ (95\% CI $-0.47-0.54$; Figure 2$)$. Statistical heterogeneity was low with an I-squared of 
$\sim 0 \%$. Fisher et al (2011) reported airflow resistance for the individual layers of 6 N95 FFR models[27] following UVGI. The airflow resistance of the individual filtering layers ranged from 2.5 to $7.6 \mathrm{~mm} \mathrm{H}_{2} \mathrm{O}$.

\section{Germicidal}

Seven studies evaluated the germicidal impact of one or more UVGI interventions[7,8,26-30], including one study on bacteria, and 5 studies on viruses (Table IV). The most common were H1N1 and MS2, used as the viral pathogen in two studies each. Lin et al was the only group to use a bacterial pathogen. Using a water medium, they looked at the relative survival of Bacillus subtilis prototype strains following exposure to a range of UV-C doses from 11,340 to $226,800 \mathrm{~J} / \mathrm{m}^{2}$. Relative survival following UVGI was $0.8 \pm 0.4$ for the lowest dose, $0.2 \pm 0.14$ for the second lowest dose, and $0 \pm 0$ for the three higher doses.

One mask was removed from the viral analysis as an outlier. Fisher et al reported a log reduction in viral load of $0.1 \pm 0.2$ for the Cardinal N95-ML in contrast to $2.9 \pm 0.2$ and $>4.8$ for the other masks they evaluated[27]. The low log reduction for the Cardinal N95-ML was attributed to a high-shielding outer mask layer that limited the amount of UV-C that reached the filter layers of the mask. Collapsing the viral studies (see Methods) resulted in 30 different UVGI arms, evaluating doses ranging from 1,500 to $72,000 \mathrm{~m} / \mathrm{J}^{2}$ (Table V). $53 \%(\mathrm{n}=16)$ of UVGI arms used a water medium vs. $47 \%(\mathrm{n}=17)$ who used another medium such as beef extract, 271B, or artificial saliva. All fifteen UVGI arms that administered a cumulative dose $>20,000$ $\mathrm{m} / \mathrm{J}^{2}$ observed a $\geq 2 \log$ reduction in viral load compared to $73 \%(\mathrm{n}=11)$ of the 15 UVGI intervention arms that administered a cumulative dose $<20,000 \mathrm{~m} / \mathrm{J}^{2}$. The average log reduction for the UVGI intervention arms that administered a dose above or below $20,000 \mathrm{~J} / \mathrm{m}^{2}$ was $3.61 \pm$ 
0.99 and $3.14 \pm 1.09$ respectively. $\mathrm{A} \geq 3 \log$ reduction was observed in $73 \%(\mathrm{n}=11)$ of UVGI arms administering a dose $>20,000 \mathrm{~J} / \mathrm{m} 2$ and $86 \%(\mathrm{n}=7)$ of UVGI arms administering a cumulative dose $>40,000 \mathrm{~J} / \mathrm{m}^{2}$. The average $\log$ reduction when using a dose $>40,000 \mathrm{~J} / \mathrm{m}^{2}$ was $3.74 \pm 0.98$. The exploratory Figure 3 suggests that the cumulative UVGI dose seems to have a greater effect on viral load in those lab trials where the viral particles were applied to the mask not using water. If mask performance in a clinical practice environment is more similar to the non-water medium (because organic matter and viral particles are found on masks), then the intensity of the UVGI light may affect the decontamination process.

\section{Physical characteristics}

Six studies were identified that evaluated some aspect of change in physical appearance and odor[7,9,24,25,31,32] or fit[31,32] (Appendix C). All six studies assessed physical appearance using visual inspection, with one study also performing a manual inspection for changes in texture and feel[9]. Three studies evaluated change in odor by sniffing the FFRs postUVGI exposure[9,25,31]. Viscusi et al[31] also determined subjects' perception of odor strength using a visual analog scale. There were no significant changes in physical appearance, texture or odor to any mask model following UVGI exposure.

Only two studes assessed fit. Viscusi et al performed an eight exercise standardized fit test pre-UVGI exposure, followed by a multi-donning fit test post-UVGI exposure[31]. A multidonning fit factor $\left(\mathrm{MDFF}_{10}\right)$ was calculated as the harmonic mean of the $10 \mathrm{FFs}$ resulting from the replicate multidonning fit test sessions. FF was the Fit Factor calculated by the PORTACOUNT Fit Tester as the ratio of the ambient particle concentration outside the respirator compared with the particle concentration inside the respirator. The MDIFF 10 value 
following UVGI treatment was favourable. The average $\mathrm{MDIFF}_{10}$ value following UVGI treatment was $138.3 \pm 28.5$ versus $142.7 \pm 27.2$ for control. None of the 6 masks showed a statistically significant difference in $\mathrm{MDIFF}_{10}$ between arms. The strap of one FFR treated with UVGI broke during the multi-donning fit test, compared to straps from 3 FFRs in the control group. Bergman et al[32] used a similar approach but employed 1, 2 and 3 cycles of UVGI on three different N95 models. Three cycles of UVGI did not cause significant changes in mask fit. The passing rate for the 3M 1860 was $95 \%, 100 \%$ and $100 \%$ after 1, 2 and 3 cycles respectively. The passing rate for the $3 \mathrm{M} 1870$ was $100 \%$ after 1,2 and 3 cycles. The passing rate for the $\mathrm{KC}$ PFR95-270 (46767) was 95\%, 95\% and 90\% after 1, 2 and 3 cycles.

\section{Other Evaluations}

Lindsley et al[22] evaluated the strength of FFR straps following UV-C exposure. The breaking strength of the respirator straps decreased after UVGI exposure compared to paired controls by $10-21 \%$ (UV-C dose $590 \mathrm{~J} / \mathrm{cm}^{2}$ ) to $20-51 \%$ (UV-C dose $2360 \mathrm{~J} / \mathrm{cm}^{2}$ ). Viscusi et al[31] evaluated subject experiences on perceived donning ease and FFR comfort following UVGI exposure using a visual analog scale, as well as responses to an open-ended statement, “Tell us something about this respirator". Donning ease and FFR comfort was not affected by UVGI, and no distinct patterns were identified in the open-ended comments.

\section{Risk of Bias}

Studies were assessed for Risk of Bias. All of the study designs included an untreated or control arm for comparison. Six studies[9,22,24,25,31,32] reported that the N95 FFRs all came from the same lot, and nine studies[7-9,24,26,28,30-32] stated that laboratory conditions were identical between intervention arms. No studies reported that outcome assessors were blinded, 
however, the subjects participating in the fit testing in Viscusi et al[31] were blinded to whether they were evaluating an FFR from the control or intervention arm. There was uncertainty regarding the risk of bias for the germicidal outcomes, as it was not clear whether the individuals performing the evaluations were blinded to treatment arm and/or UVGI dose. The outcome measures related to mask function were evaluated objectively (i.e. aerosol penetration, airflow resistance measured using a machine). (Appendix D).

\section{Discussion}

This is the first systematic review to synthesize the existing evidence on decontamination of N95 FFRs using UVGI. We found that a single cycle of UVGI with UV-C light does not affect N95 FFR performance, and was able to decontaminate mask surfaces exposed to viruses in laboratory conditions without significant changes in FFR appearance or odor. We observed that level of decontamination was associated with cumulative UV dose and the conditions used to simulate viral spread, specifically the addition of salts and biological particulate (saliva and protein). The limited body of evidence evaluating UVGI impact on physical characteristics and fit did not present evidence of negative effects

This systematic review identified 5 studies that reported on changes in aerosol penetration following UVGI. NIOSH has established a 95\% filter efficiency standard (i.e. a filter penetration of $<5 \%$ ) for N95 FFR [14]. All five studies that reported on aerosol penetration adhered to NIOSH testing standards, using a $\mathrm{NaCl}$ aerosol with a particle size of $300 \mathrm{~nm}$. Results showed minimal change in filter efficiency following the application of multiple different UVGI protocols on a variety of FFR models, and all FFRs evaluated maintained the standard filter 
efficiency of $\geq 95 \%$. A recent report from N95 FFR manufacturer 3M on N95 decontamination and reuse emphasizes the critical importance of ensuring the decontamination method does not compromise filter performance[16]. The report also includes the results of an internal study which found that 3M N95 FFRs maintained a filter efficiency of 95\% following repeated UVGI exposure (5-10 UV-C cycles), however they did not provide sufficient information to calculate a cumulative UVGI dose. In addition to standards for filter efficiency, NIOSH has also established standards for airflow resistance of N95 FFRs. Testing is performed using a filter tester at 85 L/min of constant airflow, and to meet certification requirements, N95 FFRs must demonstrate a peak average inhalation of $35 \mathrm{~mm}(343.2 \mathrm{~Pa})$ and an exhalation resistance to airflow $25 \mathrm{~mm}$ (245.1 Pa) $\mathrm{H}_{2} \mathrm{O}$ pressure[33]. This systematic review found three studies that evaluated airflow filtration using standardized testing protocols following UVGI. None of the seven FFRs evaluated across the three studies demonstrated significant changes in airflow filtration following UVGI, and all FFRs maintained the NIOSH airflow standards.

Mask fit is another important consideration, as improper fit results in an inadequate seal of the mask against the wearers face, reducing the mask's ability to prevent particle penetration[34]. Fit testing is performed according to the Occupational Safety and Health Administration (OSHA) respiratory protection regulation using a PORTACOUNT Fit Tester to determine the volume of test substance that is leaking into the mask. Only two papers were identified that evaluated FFR fit following UVGI exposure. While the results from Viscusi et al[31] and Bergman et al[32] showed no significant change in mask fit following UVGI, they both used a modified version of the OSHA fit testing protocol following UVGI decontamination. Further, the fit testing was not performed in real world conditions. Therefore, the evidence regarding the effects of UVGI on FFR fit is limited. Further investigation using additional UVGI 
protocols and mask models in a clinical setting is required in order to confirm whether or not UVGI alters the fit of N95 respirators.

The six studies that evaluate on changes in mask appearance following UVGI did not report any significant changes in physical appearance or odor following a single cycle of UVGI exposure[7,9,24,31], a single continuous exposure equivalent to 3 cycles of UVGI[25] or 3 cycles of UVGI[32]. This is in contrast to the report by 3M, who observed physical degradation of their FFRs following 5 to 10 cycles of UVGI. As a result, 3M still does not recommend decontamination and reuse of N95 FFRs at this time[16]. It is likely that the physical observation observed by $3 \mathrm{M}$ was due to the number of UVGI cycles employed. Therefore, there may be a limit on the number of UVGI cycles that can be applied to a given FFR before the mask begins to breakdown. Further, there is evidence that mask fit deteriorates through repeated donning and doffing[35] but with careful donning, 5 safe reuses appear possible[36]. The number of decontamination and re-use cycles that can be applied to a FFR will be limited by breakdown imposed by both UVGI and donning and doffing.

While maintaining the function and fit of the FFR critically, an equally important metric for evaluating UVGI protocols is their ability to eradicate infectious material from the mask surface. The seven studies that reported on decontamination demonstrated that exposure to UV-C light can significantly reduce the number of viable viral pathogens from N95 FFR, with cumulative doses of $>20,000 \mathrm{~J} / \mathrm{m} 2$ and $>40,000 \mathrm{~J} / \mathrm{m}^{2}$ consistently resulting in log reductions of $\geq 2$ and $\geq 3$ respectively. However, it is important to note that these evaluations were all performed in a laboratory setting and do not represent real world conditions. There is rationale to suggest that the decontamination effect of UVGI could actually be more effective in the real world setting. Mills et al overloaded the mask surface with more virus than would be observed 
following a real life contamination event, yet still observed $\geq 3 \log$ reduction in viral load on 12 of the 15 masks evaluated[28]. Of note, the fact that a significant reduction was not observed in all 15 masks suggests that mask model and material should be considered as factors that may influence the success of UVGI decontamination. For example, Fisher et al reported a log reduction of $0.1 \pm 0.2$ for the Cardinal N95-ML in contrast to $2.9 \pm 0.2$ and $>4.8$ for the other masks evaluated[27], which was attributed to a high-shielding outer mask layer that limited the amount of UV-C that reached the filter layers of the mask.

Additional evidence that decontamination may be more effective in the real world setting comes from the time elapsed between UVGI and measurement of pathogens in the studies examined. The majority of authors measured pathogen levels immediately following UVGI decontamination. The one study by Lin et al that measured bacterial levels immediately after, and 24 hours after, UVGI found that bacterial levels were further reduced by 24 hours[8]. This is despite the fact that the mask material was stored in worst-case temperature $\left(37^{\circ} \mathrm{C}\right)$ and humidity (95\% RH) conditions for the 24 hour period. It is well established that bacteria and virus levels on surfaces decrease over time[37,38]. In the real world setting, FFRs undergoing UVGI decontamination could be allowed to sit for an extended period of time (e.g. 24 hours) prior to re-use, in order to further enhance the decontamination process. Regardless of the UVGI protocol ultimately selected, a recent study of SARS-CoV-2 persistence on a variety of surfaces showing, at minimum, a one log decline in infectivity every 24 hrs suggests that, where possible, a one week holding period for respirators following decontamination will materially decrease risk of viral persistence[39].

Overall the evidence demonstrating that N95 FFR performance is maintained following a single cycle UVGI can be classified as strong. Findings were consistent across multiple studies, 
aerosol penetration and airflow filtration are measured objectively, and all studies that reported on FFR function used a control arm in their study design. The evidence regarding the effectiveness of UVGI to decontaminate mask material is less strong. Although findings were also consistent across studies and a control group was always incorporated into study design, outcome assessors were not blinded. Further, the existing evidence is all laboratory based, and is not reflective of real world conditions. Data regarding the effect of UVGI on FFR fit is limited, thus it is not possible to definitely conclude whether or not this method of decontamination alters the fit of N95 masks.

Based on the available evidence, we recommend a cumulative dose of no less than 20,000 and ideally $40,000 \mathrm{~J} / \mathrm{m}^{2}$ be used for clinical application of UVGI and/or further investigation. The $40,000 \mathrm{~J} / \mathrm{m}^{2}$ cumulative dose consistently resulted in $\geq 3 \log$ reduction in viral pathogens. Modelling derived by Fisher et al for influenza contamination of FFRs from aerosol sources showed full decontamination would require a log reduction of 3[40]. In addition, this dose has been shown to not alter FFR performance (particle penetration, airflow resistance). Data from one study that evaluated mask fit following a comparable dose of UVGI $(32,400 \mathrm{~J} / \mathrm{m} 2)$ showed no change in mask fit, but additional investigation would be prudent.

\section{Limitations}

Although this systematic review provides valuable information regarding the possibility of UVIG decontamination for the safe reuse of FFR, a number of limitations must be acknowledged. Each study used a different combination of mask types. In order to address this we aggregated across mask types within each study, treating the pooled replicates across mask types as our statistically independent sampling unit. This is appropriate for our research question aimed at performance of FFRs in general (where we assume little difference between mask 
types). If there are large differences between mask types, our approach might artificially inflate our sample size; if this were the case it would unlikely change our findings, due to the consistency of these studies conclusions and low heterogeneity.

\section{Conclusions}

The function of N95 masks, based on aerosol penetration and airflow filtration, is maintained following a single cycle of UVGI. Decontamination using UV light in the laboratory setting suggests that this can be a successful method of removing infectious pathogens from FFRs. Future studies should use a cumulative UV-C dose of $40,000 \mathrm{~J} / \mathrm{m}^{2}$ and focus on validating the effectiveness of UVGI decontamination in the real world setting, and on determining the impact of UVGI on mask fit. 
Acknowledgements: We are grateful to Nafisa Neault for her assistance in verifying the information in tables I to $\mathrm{V}$.

\section{Declarations of Interest: None}

Source of Funding: This research did not receive any specific grant from funding agencies in the public, commercial, or not-for-profit sectors 


\section{References}

[1] Bałazy, A., Toivola, M., Adhikari, A., Sivasubramani, S., T, R. \& Grinshpun, S. Do n95 respirators provide $95 \%$ protection level against airborne viruses, and how adequate are surgical masks? American Journal of Infection Control 2006; 34: 49-56.

[2] Tan, N., Goh, L. \& Lee, S. Family physicians' experiences, behaviour, and use of personal protection equipment during the sars outbreak in singapore: Do they fit the becker health belief model?. Asia Pacific Journal of Public Health 2006; 18: 49-56. .

[3] Centre for disease control and prevention. Strategies for optimizing the supply of $n 95$

respirators: Conventional capacity strategies., https://www.cdc.gov/coronavirus/2019ncov/hcp/respirators-strategy/conventional-capacity-strategies.html; [Accessed March 28. 2020] [4] Patel, A., D'Alessandro, M. M., Ireland, K. J., Burel, W. G., Wencil, E. B. \& Rasmussen, S. A. Personal protective equipment supply chain: Lessons learned from recent public health emergency responses. Health Secur 2017; 15: 244-252. doi:10.1089/hs.2016.0129.

[5] Srinivasan, A., Jernign, D. B., Liedtke, L. \& Strausbaugh, L. Hospital preparedness for severe acute respiratory syndrome in the united states: Views from a national survey of infectious diseases consultants. Clin Infect Dis 2004; 39: 272-274. doi:10.1086/421777. [6] Bauchner, H., Fontanarosa, P. B. \& Livingston, E. H. Conserving supply of personal protective equipment-a call for ideas. JAMA 2020; doi:10.1001/jama.2020.4770.

[7] Heimbuch, B. K., Wallace, W. H., Kinney, K., Lumley, A. E., Wu, C. Y., Woo, M. H. \& Wander, J. D. A pandemic influenza preparedness study: Use of energetic methods to decontaminate filtering facepiece respirators contaminated with $\mathrm{h} 1 \mathrm{n} 1$ aerosols and droplets. American Journal of Infection Control 2011; 39: e1-9.

doi:https://dx.doi.org/10.1016/j.ajic.2010.07.004.

[8] Lin, T. H., Tang, F. C., Hung, P. C., Hua, Z. C. \& Lai, C. Y. Relative survival of bacillus subtilis spores loaded on filtering facepiece respirators after five decontamination methods. Indoor Air 2018; 31: 31. doi:https://dx.doi.org/10.1111/ina.12475.

[9] Viscusi, D. J., Bergman, M. S., Eimer, B. C. \& Shaffer, R. E. Evaluation of five decontamination methods for filtering facepiece respirators. Annals of Occupational Hygiene 2009; 53: 815-827. doi:https://dx.doi.org/10.1093/annhyg/mep070.

[10] Reed, N. G. The history of ultraviolet germicidal irradiation for air disinfection. Public Health Rep 2010; 125: 15-27. doi:10.1177/003335491012500105.

[11] Agrawal, S. K., Dahal, S., Bhumika, T. V. \& Nair, N. S. Evaluating sanitization of toothbrushes using various decontamination methods: A meta-analysis. J Nepal Health Res Counc 2019; 16: 364-371.

[12] Napolitani, M., Bezzini, D., Moirano, F., Bedogni, C. \& Messina, G. Methods of disinfecting stethoscopes: Systematic review. Int J Environ Res Public Health 2020; 17: doi:10.3390/ijerph17061856.

[13] Ahmed, I., Fang, Y., Lu, M., Yan, Q., El-Hussein, A., Hamblin, M. R. \& Dai, T. Recent patents on light-based anti-infective approaches. Recent Pat Antiinfect Drug Discov 2018; 13 : 70-88. doi:10.2174/1872213X11666171108104104. 
[14] National institute for occupational safety and health. Niosh guide to the selection and use of particulate respirators, https://www.cdc.gov/niosh/docs/96-101/default.html; 1996 [Accessed March 27, 2020]

[15] Lowe, J. J., Paladino, K. D., Farke, J. D., Boulter, K., Cawcutt, K., Emodi, M., Gibbs, S., Hankins, R., Hinkle, L., Micheels, T., Schwedhelm, S., Vasa, A., Wadman, M., Watson, S. \& Rupp, M. E. N95 filtering facemask receptor ultraviolet germicidal irradiation (uvgi) process for decontamination and reuse. Nebraska Medicine 2020.

[16] 3m. Disinfection of filtering facepiece respirators, https://multimedia.3m.com/mws/media/1816576O/disinfection-of-disposable-respiratorstechnical-bulletin.pdf; 2020 [Accessed March 27, 2020]

[17] Moher, D., Liberati, A., Tetzlaff, J., Altman, D. G. \& Group, P. Preferred reporting items for systematic reviews and meta-analyses: The prisma statement. Int J Surg 2010; 8: 336-341. doi:10.1016/j.ijsu.2010.02.007.

[18] Harris, P. A., Taylor, R., Minor, B. L., Elliott, V., Fernandez, M., O'Neal, L., McLeod, L., Delacqua, G., Delacqua, F., Kirby, J., Duda, S. N. \& Consortium, R. E. The redcap consortium: Building an international community of software platform partners. J Biomed Inform 2019; 95: 103208. doi:10.1016/j.jbi.2019.103208.

[19] Harris, P. A., Taylor, R., Thielke, R., Payne, J., Gonzalez, N. \& Conde, J. G. Research electronic data capture (redcap)--a metadata-driven methodology and workflow process for providing translational research informatics support. J Biomed Inform 2009; 42: 377-381. doi:10.1016/j.jbi.2008.08.010.

[20] R core team (2012). R: A language and environment for statistical computing. $R$ foundation for statistical computing, vienna, austria. Isbn 3-900051-07-0, url http://www.R-project.Org/. [21] Balduzzi, S., Rücker, G. \& Schwarzer, G. How to perform a meta-analysis with r: A practical tutorial. Evidence-Based Mental Health 2019; 22: 153-160.

[22] Lindsley, W. G., Martin, S. B., Jr., Thewlis, R. E., Sarkisian, K., Nwoko, J. O., Mead, K. R. \& Noti, J. D. Effects of ultraviolet germicidal irradiation (uvgi) on $\mathrm{n} 95$ respirator filtration performance and structural integrity. J Occup Environ Hyg 2015; 12: 509-517.

doi:https://dx.doi.org/10.1080/15459624.2015.1018518.

[23] Jinadatha, C., Simmons, S., Dale, C., Ganachari-Mallappa, N., Villamaria, F. C., Goulding, N., Tanner, B., Stachowiak, J. \& Stibich, M. Disinfecting personal protective equipment with pulsed xenon ultraviolet as a risk mitigation strategy for health care workers. American Journal of Infection Control 2015; 43: 412-414. doi:https://dx.doi.org/10.1016/j.ajic.2015.01.013. [24] Viscusi, D. J., King, W. P. \& Shaffer, R. E. Effect of decontamination on the filtration efficiency of two filtering facepiece respirator models. Journal of the International Society for Respiratory Protection 2007; 24: 93-106.

[25] Bergman, M. S., Viscusi, D. J., Heimbuch, B. K., Wander, J. D. \& Sambol, A. R. Evaluation of multiple (3-cycle) decontamination processing for filtering facepiece respirators. DigitalCommons@University of Nebraska - Lincoln. 2010.

[26] Lore, M. B., Heimbuch, B. K., Brown, T. L., Wander, J. D. \& Hinrichs, S. H. Effectiveness of three decontamination treatments against influenza virus applied to filtering facepiece respirators. Annals of Occupational Hygiene 2012; 56: 92-101. doi:https://dx.doi.org/10.1093/annhyg/mer054.

[27] Fisher, E. M. \& Shaffer, R. E. A method to determine the available uv-c dose for the decontamination of filtering facepiece respirators. Journal of applied microbiology 2010. 
[28] Mills, D., Harnish, D. A. \& Lawrence, C. Ultraviolet germicidal irradiation of influenzacontaminated n95 filtering facepiece respirators. American journal of ... 2018.

[29] Vo, E., Rengasamy, S. \& Shaffer, R. Development of a test system to evaluate procedures for decontamination of respirators containing viral droplets. Appl Environ Microbiol 2009; 75: 7303-7309. doi:https://dx.doi.org/10.1128/AEM.00799-09.

[30] Woo, M. H., Smith, T., Wu, C. Y., Grippin, A. \& Anwar, D. Effects of relative humidity and spraying medium on ultraviolet (uv) decontamination of filters loaded with viral aerosols. (apps.dtic.mil, 2012).

[31] Viscusi, D. J., Bergman, M. S., Novak, D. A., Faulkner, K. A., Palmiero, A., Powell, J. \& Shaffer, R. E. Impact of three biological decontamination methods on filtering facepiece respirator fit, odor, comfort, and donning ease. J Occup Environ Hyg 2011; 8: 426-436. doi:https://dx.doi.org/10.1080/15459624.2011.585927. [32] Bergman, M. S., Viscusi, D. J., Palmiero, A. J., Powell, J. B. \& Shaffer, R. E. Impact of three cycles of decontamination treatments on filtering facepiece respirator fit. Journal of the International Society for Respiratory Protection 2011; 28: 48-59.

[33] 2. Code offederal regulations (42 cfr 84.180). Airflow resistance tests., [Accessed March 29, 2020]

[34] Reponen, T., Lee, S. A., Grinshpun, S. A., Johnson, E. \& McKay, R. Effect of fit testing on the protection offered by $\mathrm{n} 95$ filtering facepiece respirators against fine particles in a laboratory setting. Ann Occup Hyg 2011; 55: 264-271. doi:10.1093/annhyg/meq085.

[35] Vuma, C. D., Manganyi, J., Wilson, K. \& Rees, D. The effect on fit of multiple consecutive donning and doffing of $\mathrm{n} 95$ filtering facepiece respirators. Ann Work Expo Health 2019; 63: 930936. doi:10.1093/annweh/wxz060.

[36] Bergman, M. S., Viscusi, D. J., Zhuang, Z., Palmiero, A. J., Powell, J. B. \& Shaffer, R. E. Impact of multiple consecutive donnings on filtering facepiece respirator fit. American Journal of Infection Control 2012; 40: 375-380. doi:10.1016/j.ajic.2011.05.003.

[37] Bean, B., Moore, B. M., Sterner, B., Peterson, L. R., Gerding, D. N. \& Balfour, H. H., Jr. Survival of influenza viruses on environmental surfaces. J Infect Dis 1982; 146: 47-51. doi:10.1093/infdis/146.1.47.

[38] Yeargin, T., Buckley, D., Fraser, A. \& Jiang, X. The survival and inactivation of enteric viruses on soft surfaces: A systematic review of the literature. Am J Infect Control 2016; 44: 1365-1373. doi:10.1016/j.ajic.2016.03.018.

[39] van Doremalen, N., Bushmaker, T., Morris, D. H., Holbrook, M. G., Gamble, A., Williamson, B. N., Tamin, A., Harcourt, J. L., Thornburg, N. J., Gerber, S. I., Lloyd-Smith, J. O., de Wit, E. \& Munster, V. J. Aerosol and surface stability of sars-cov-2 as compared with sarscov-1. N Engl J Med 2020; doi:10.1056/NEJMc2004973.

[40] Fisher, E. M., Noti, J. D., Lindsley, W. G., Blachere, F. M. \& Shaffer, R. E. Validation and application of models to predict facemask influenza contamination in healthcare settings. Risk Anal 2014; 34: 1423-1434. doi:10.1111/risa.12185. 
Figure 1: PRISMA Flow Diagram

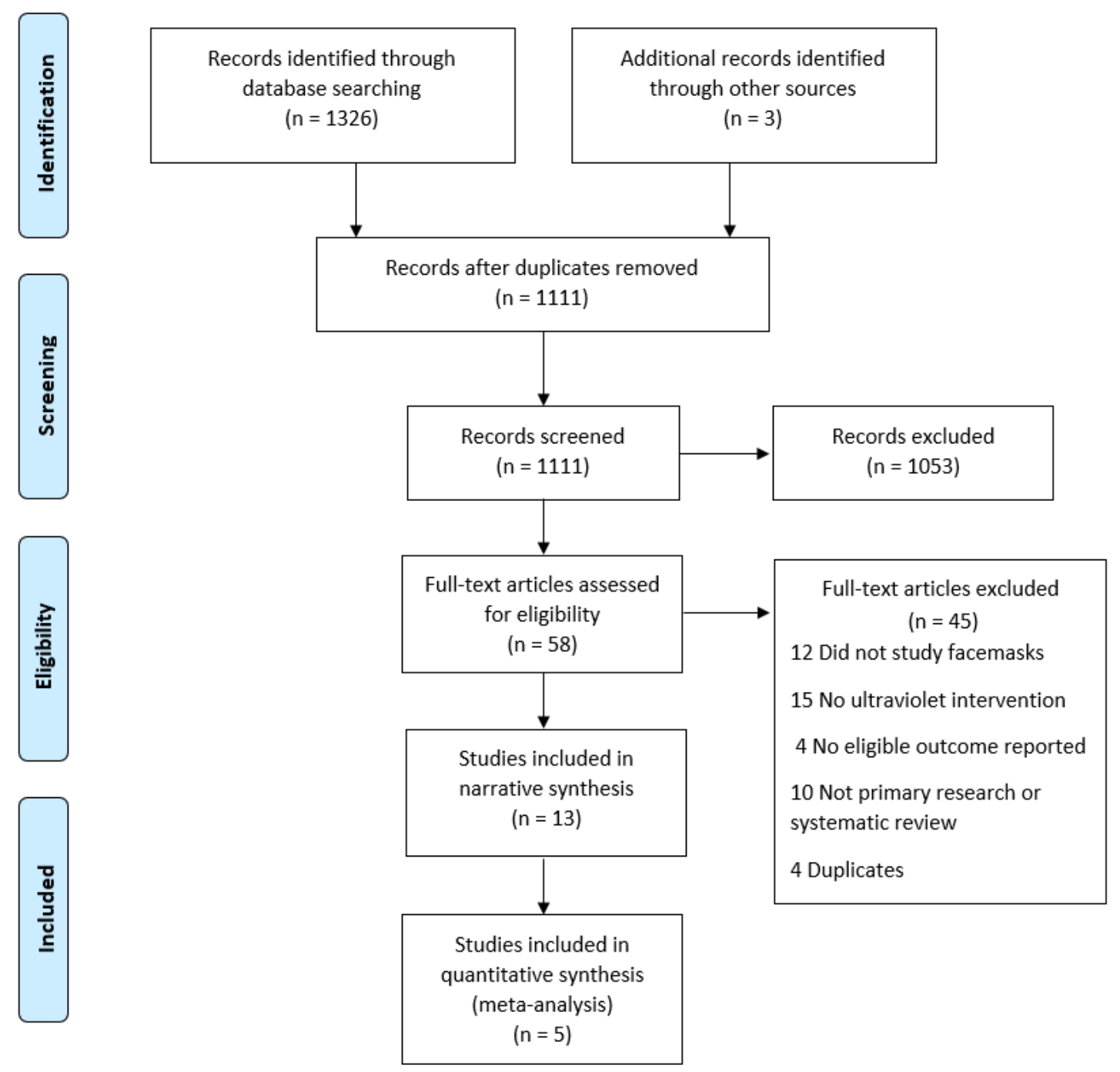


Figure 2: Pooled Results assessing Particle Penetration and Airflow Resistance.

A. $\begin{array}{ll}\text { Experimental } & \text { Control } \\ \text { Total Mean SD Total Mean SD }\end{array}$ Study

Mean Difference

$\begin{array}{llll}3 & 1.18 & 0.2133\end{array}$

Bergman et al (2010)

Lindsley et al (2015)

Lore et al (2012)

Viscusi et al (2007)

Random effects model

Prediction interval

Heterogeneity: $I^{2}=0 \%, \tau^{2}=0.0041, p=0.84$ $\begin{array}{llll}4 & 2.48 & 0.3750\end{array}$

$\begin{array}{llll}5 & 0.74 & 0.1650\end{array}$

$\begin{array}{llll}4 & 0.70 & 0.2700\end{array}$

$\begin{array}{llll}3 & 0.87 & 0.5533\end{array}$

19
Viscusi et al (2009)

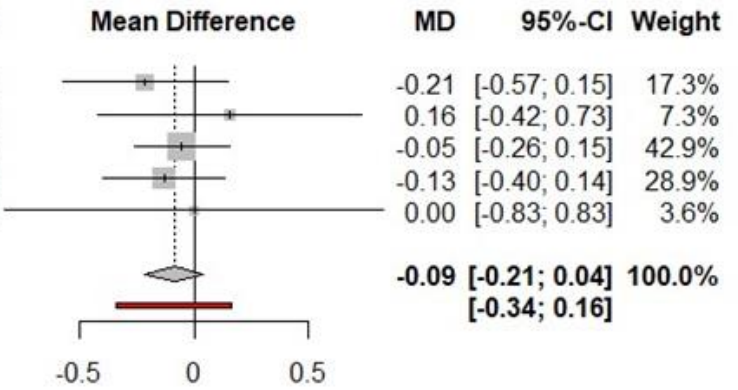

B.

Study Total Mean SD Total Mean SD

Bergman et al (2010)

Viscusi et al (2009)

Lindsley et al (2015)

$\begin{array}{llll}3 & 9.77 & 0.3300\end{array}$

$\begin{array}{llll}3 & 8.33 & 0.7000\end{array}$

$4 \begin{array}{lll}41.44 & 0.7050\end{array}$

$\begin{array}{lll}3 & 9.70 & 0.2300\end{array}$

$\begin{array}{llll}3 & 7.97 & 1.0400\end{array}$

$4 \begin{array}{lll}41.70 & 0.7175\end{array}$

Random effects model 10

Prediction interval

10

Heterogeneity: $I^{2}=0 \%, \tau^{2}=0.0156, p=0.75$
Mean Difference $\quad$ MD $\quad 95 \%-\mathrm{Cl}$ Weight

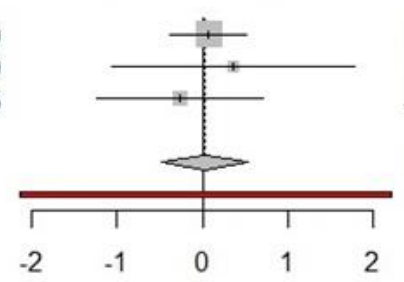

$0.07[-0.39 ; 0.53] \quad 72.0 \%$

$0.36[-1.06 ; 1.78] \quad 9.3 \%$

$-0.27[-1.25 ; 0.72] \quad 18.7 \%$

$0.03[-0.47 ; 0.54] 100.0 \%$

$[-2.15 ; 2.22]$

The forest plot in A illustrates the mean particle penetration in masks. The experimental arm refers to the UVGI - Ultraviolet germicidal irradiation, treated arm. Mask type examined varied by study; Bergman et al (N95-A,N95-B,N95-C), Lindsley et al (3M 1860, 3M 9210, GE 1730,KC 46727), Lore et al (3M 1860, 3M 1870), Viscusi et al 2007 (N95), and Viscusi et al 2009 (N95-A,N95-B,N95-C). The forest plot in B illustrates the mean airflow resistance in masks. The experimental arm refers to the UVGI - Ultraviolet germicidal irradiation, treated arm. Mask type examined varied by study; Bergman et al (N95-A, N95-B, N95-C), Viscusi et al 2009 (N95-A, N95-B, N95-C) and Lindsley et al (3M 1860, 3M 9210, GE 1730, KC 46727). Total refers to the number of replicates per mask. 
Figure 3: Ultraviolet germicidal irradiation cumulative dose by log change in viral load in trials that used a water versus a non-water medium

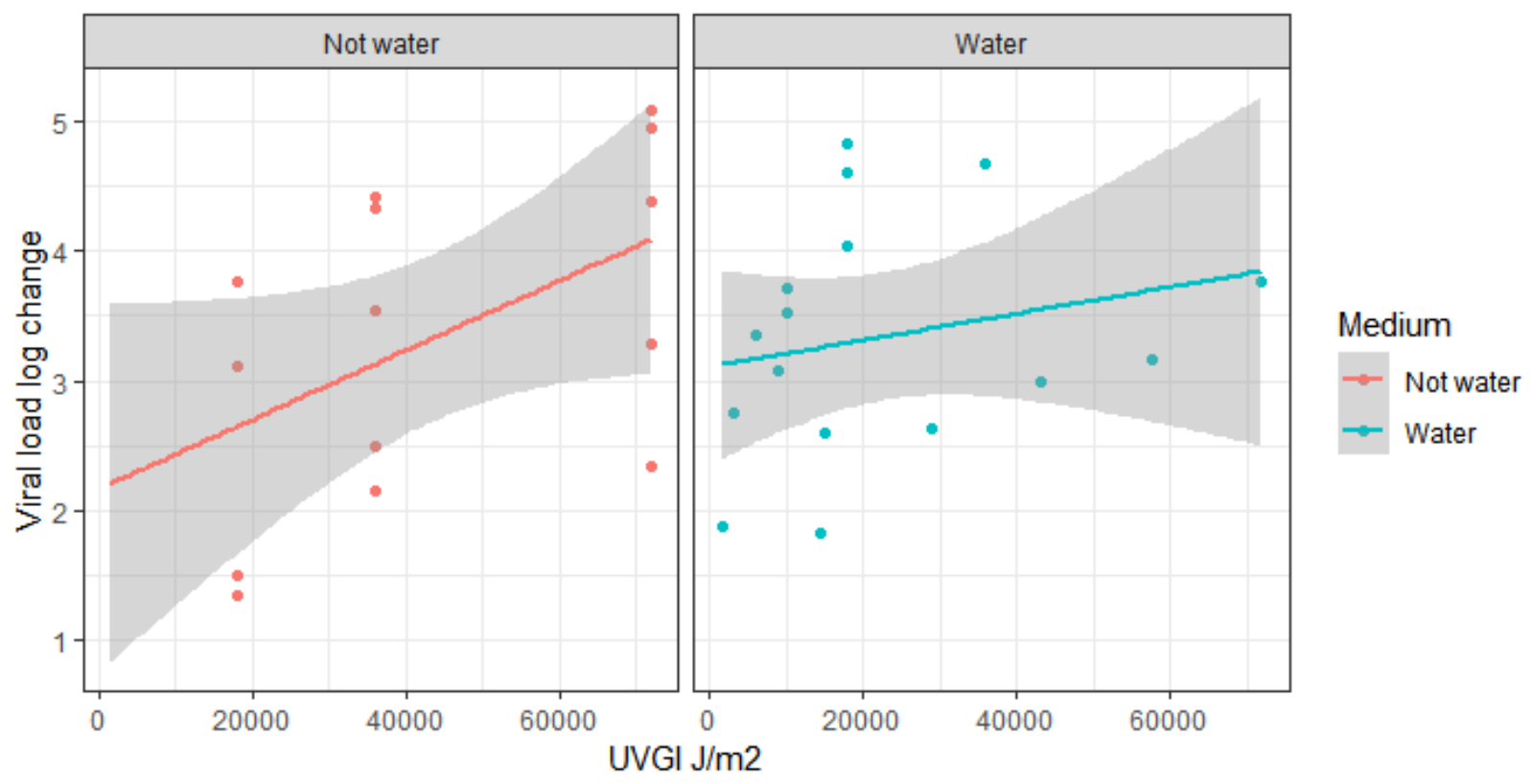

Scatter plot showing the relationship between the cumulative UVGI dose $\left(\mathrm{J} / \mathrm{m}^{2}\right)$ and viral load log change post UVGI. The two horizontal panels represent the medium (or solution) in which the viral particles were applied to the face mask, for these lab trials. Note, this is a descriptive plot and not a meta-regression. 
Table I: Characteristics of studies included in a systematic review of UVGI on N95 filtering facepiece respirators

\begin{tabular}{|c|c|c|c|c|c|c|c|c|c|c|}
\hline \multirow[b]{2}{*}{ Author } & \multirow{2}{*}{$\begin{array}{c}\text { Year of } \\
\text { publication }\end{array}$} & \multirow{2}{*}{$\begin{array}{c}\text { Country of } \\
\text { origin }\end{array}$} & \multirow{2}{*}{$\begin{array}{c}\text { Number } \\
\text { of UVGI } \\
\text { arms }\end{array}$} & \multirow{2}{*}{$\begin{array}{c}\text { Number } \\
\text { of N95 } \\
\text { models }\end{array}$} & \multicolumn{6}{|c|}{ Outcomes Evaluated } \\
\hline & & & & & $\begin{array}{c}\text { Number of } \\
\text { conditions }\end{array}$ & $\begin{array}{c}\text { Aerosol } \\
\text { penetration }\end{array}$ & $\begin{array}{c}\text { Airflow } \\
\text { resistance }\end{array}$ & Decontamination & Fit & $\begin{array}{c}\text { Physical } \\
\text { appearance }\end{array}$ \\
\hline Bergman & 2010 & $\begin{array}{l}\text { United } \\
\text { States }\end{array}$ & 1 & 6 & 1 & Yes & Yes & No & No & Yes \\
\hline Bergman & 2011 & $\begin{array}{l}\text { United } \\
\text { States }\end{array}$ & 1 & 3 & 1 & No & No & No & Yes & Yes \\
\hline Fisher & 2010 & $\begin{array}{l}\text { United } \\
\text { States }\end{array}$ & 22 & 6 & 1 & No & No & MS2 & No & No \\
\hline Heimbuch & 2011 & $\begin{array}{l}\text { United } \\
\text { States }\end{array}$ & 1 & 6 & 2 & No & No & $\begin{array}{l}\text { H1N1 aerosols } \\
\text { and droplets }\end{array}$ & No & Yes \\
\hline Lin & 2018 & East Asia & 10 & 1 & 2 & No & No & $\begin{array}{l}\text { Bacillus subtilis } \\
\text { prototype strains }\end{array}$ & No & No \\
\hline Lindsley & 2015 & $\begin{array}{l}\text { United } \\
\text { States }\end{array}$ & 5 & 4 & 1 & Yes & Yes & No & No & No \\
\hline Lore & 2012 & $\begin{array}{l}\text { United } \\
\text { States }\end{array}$ & 1 & 2 & 1 & Yes & No & $\begin{array}{c}\text { Influenza } \\
\text { A/H5N1 } \\
\text { (VNH5N1) }\end{array}$ & No & No \\
\hline Mills & 2018 & $\begin{array}{l}\text { United } \\
\text { States }\end{array}$ & 1 & 15 & 2 & No & No & $\mathrm{H} 1 \mathrm{~N} 1$ influenza & No & No \\
\hline Viscusi & 2007 & $\begin{array}{l}\text { United } \\
\text { States }\end{array}$ & 2 & 1 & 1 & Yes & No & No & No & Yes \\
\hline Viscusi & 2009 & $\begin{array}{l}\text { United } \\
\text { States }\end{array}$ & 1 & 6 & 1 & Yes & Yes & No & No & Yes \\
\hline Viscusi & 2011 & $\begin{array}{l}\text { United } \\
\text { States }\end{array}$ & 1 & 6 & 1 & No & No & No & Yes & Yes \\
\hline Vo & 2009 & $\begin{array}{l}\text { United } \\
\text { States }\end{array}$ & 5 & 1 & 1 & No & No & MS2 & No & No \\
\hline Woo & 2012 & $\begin{array}{l}\text { United } \\
\text { States }\end{array}$ & 3 & 1 & 9 & No & No & MS2 & No & No \\
\hline
\end{tabular}

Abbreviations: UVGI - Ultraviolet germicidal irradiation 
Table II: UVGI interventions and N95 filtering facemask respirators used to evaluate UVGI decontamination on aerosol penetration

\begin{tabular}{|c|c|c|c|c|c|c|c|c|}
\hline $\begin{array}{c}\text { Author } \\
\text { and Year }\end{array}$ & $\begin{array}{c}\text { Wavelength } \\
(\mathrm{nm})\end{array}$ & $\begin{array}{c}\text { Watts } \\
(W)\end{array}$ & $\begin{array}{c}\text { Duration } \\
(\text { min })\end{array}$ & $\begin{array}{c}\text { Dose } \\
\left(\mathbf{J} / \mathbf{m}^{2}\right)\end{array}$ & $\begin{array}{c}\text { Intensity } \\
\left(\mathbf{m W} / \mathbf{c m}^{2}\right)\end{array}$ & $\begin{array}{c}\text { Distance } \\
(\mathbf{c m})\end{array}$ & UVGI Study Arms & N95 Masks Evaluated \\
\hline $\begin{array}{l}\text { Bergman, } \\
2010\end{array}$ & 254 & 40 & 45 & 48,600 & 1.8 & 25 & Single UVGI arm & $\begin{array}{c}\text { N95-A } \\
\text { N95-B } \\
\text { N95-C } \\
\text { SN95-D } \\
\text { SN95-E } \\
\text { SN95-F }\end{array}$ \\
\hline $\begin{array}{l}\text { Lindsley, } \\
2015\end{array}$ & 254 & 15 & NR & $\begin{array}{l}120,000 \text { to } \\
950,000\end{array}$ & NR & 6.2 & $\begin{array}{l}\text { Arm 1: } 120,000 \mathrm{~J} / \mathrm{m}^{2} \\
\text { Arm 2: } 240,000 \mathrm{~J} / \mathrm{m}^{2} \\
\text { Arm 3: } 470,000 \mathrm{~J} / \mathrm{m}^{2} \\
\text { Arm 4: } 710,000 \mathrm{~J} / \mathrm{m}^{2} \\
\text { Arm 5: } 950,000 \mathrm{~J} / \mathrm{m}^{2}\end{array}$ & $\begin{array}{c}\text { 3M } 1860 \\
\text { 3M } 9210 \\
\text { GE } 1730 \\
\text { Kimberley-Clark } 46727\end{array}$ \\
\hline Lore, 2012 & 254 & 15 & 15 & 18,000 & $1.6-2.2$ & 25 & Single UVGI arm & $\begin{array}{l}3 \mathrm{M} 1860 \\
3 \mathrm{M} 1870\end{array}$ \\
\hline $\begin{array}{l}\text { Viscusi } \\
2007\end{array}$ & 254 & 40 & $30-480$ & NR & NR & NR & $\begin{array}{l}\text { Arm 1: } 30 \mathrm{~min} \\
\text { Arm 2: } 480 \mathrm{~min}\end{array}$ & $\begin{array}{c}\text { N95 model }(\mathrm{n}=1) \text { not } \\
\text { specified }\end{array}$ \\
\hline $\begin{array}{l}\text { Viscusi } \\
2009\end{array}$ & 254 & 40 & 30 & $\begin{array}{c}3,520- \\
3,620\end{array}$ & 0.18 to 0.20 & NR & Single UVGI arm & $\begin{array}{c}\text { N95-A } \\
\text { N95-B } \\
\text { N95-C } \\
\text { SN95-D } \\
\text { SN95-E } \\
\text { SN95-F }\end{array}$ \\
\hline
\end{tabular}

Abbreviations: NR - Not reported; UVGI - Ultraviolet germicidal irradiation 
Table III: UVGI interventions and N95 filtering facemask respirators used to evaluate UVGI decontamination on airway filtration

\begin{tabular}{|c|c|c|c|c|c|c|c|c|}
\hline $\begin{array}{c}\text { Author } \\
\text { and Year }\end{array}$ & $\begin{array}{c}\text { Wavelength } \\
\text { (nm) }\end{array}$ & $\begin{array}{c}\text { Watts } \\
\text { (W) }\end{array}$ & $\begin{array}{c}\text { Duration } \\
\text { (min) }\end{array}$ & Dose & $\begin{array}{c}\text { Intensity } \\
\left(\mathrm{mW} / \mathrm{cm}^{2}\right)\end{array}$ & $\begin{array}{l}\text { Distance } \\
\text { (cm) }\end{array}$ & UVGI Study Arms & N95 Masks Evaluated \\
\hline $\begin{array}{l}\text { Bergman, } \\
2010\end{array}$ & 254 & 40 & 45 & 48,600 & 1.8 & 25 & Single UVGI arm & $\begin{array}{l}\text { N95-A } \\
\text { N95-B } \\
\text { N95-C } \\
\text { SN95-D } \\
\text { SN95-E } \\
\text { SN95-F }\end{array}$ \\
\hline $\begin{array}{l}\text { Lindsley, } \\
2015\end{array}$ & 254 & 15 & NR & $\begin{array}{c}120,000- \\
950,000\end{array}$ & NR & 6.2 & $\begin{array}{l}\text { Arm 1: } 120,000 \mathrm{~J} / \mathrm{m}^{2} \\
\text { Arm 2: } 240,000 \mathrm{~J} / \mathrm{m}^{2} \\
\text { Arm 3: } 470,000 \mathrm{~J} / \mathrm{m}^{2} \\
\text { Arm 4: } 710,000 \mathrm{~J} / \mathrm{m}^{2} \\
\text { Arm 5: } 950,000 \mathrm{~J} / \mathrm{m}^{2}\end{array}$ & $\begin{array}{c}\text { 3M } 1860 \\
\text { 3M } 9210 \\
\text { GE } 1730 \\
\text { Kimberley-Clark } 46727\end{array}$ \\
\hline $\begin{array}{c}\text { Viscusi } \\
2009\end{array}$ & 254 & 40 & 30 & $\begin{array}{c}3,520- \\
3,620\end{array}$ & 0.18 to 0.20 & NR & Single UVGI arm & $\begin{array}{c}\text { N95-A } \\
\text { N95-B } \\
\text { N95-C } \\
\text { SN95-D } \\
\text { SN95-E } \\
\text { SN95-F }\end{array}$ \\
\hline
\end{tabular}

Abbreviations: NR - Not reported, UVGI - Ultraviolet germicidal irradiation 
Table IV: UVGI interventions and N95 filtering facemask respirators used to evaluate UVGI decontamination on viral or bacterial load

\begin{tabular}{|c|c|c|c|c|c|c|c|c|}
\hline $\begin{array}{c}\text { Author and } \\
\text { Year }\end{array}$ & $\begin{array}{c}\text { Wavelength } \\
(\mathbf{n m})\end{array}$ & $\begin{array}{c}\text { Watts } \\
(\mathrm{W})\end{array}$ & Duration (min) & $\begin{array}{l}\text { Dose } \\
\left(\mathrm{J} / \mathbf{m}^{2}\right)\end{array}$ & $\begin{array}{c}\text { Intensity } \\
\left(\mathrm{mW} / \mathrm{cm}^{2}\right)\end{array}$ & $\begin{array}{c}\text { Distance } \\
(\mathbf{c m})\end{array}$ & UVGI Study Arms & N95 Masks Evaluated \\
\hline Fisher $2010^{\mathrm{a}}$ & NR & 40 & $1-10$ & $\begin{array}{l}1,500- \\
15,000\end{array}$ & 2.5 & $\mathrm{NR}$ & $\begin{array}{c}\text { Model A-1: } 10 \mathrm{~min}, 15000 \mathrm{~J} / \mathrm{m}^{2} \\
\text { Model C 1: } 1 \mathrm{~min}, 1500 \mathrm{~J} / \mathrm{m}^{2} \\
\text { Model C-2: } 2 \mathrm{~min}, 3000 \mathrm{~J} / \mathrm{m}^{2} \\
\text { Model C-3: } 4 \mathrm{~min}, 6000 \mathrm{~J} / \mathrm{m}^{2} \\
\text { Model C-4: } 10 \mathrm{~min}, 15,000 \mathrm{~J} / \mathrm{m}^{2} \\
\\
\text { Model F 1: } 1 \mathrm{~min}, 1500 \mathrm{~J} / \mathrm{m}^{2} \\
\text { Model F-2: } 2 \mathrm{~min}, 3000 \mathrm{~J} / \mathrm{m}^{2} \\
\text { Model F-3: } 4 \mathrm{~min}, 6000 \mathrm{~J} / \mathrm{m}^{2} \\
\text { Model F-4: } 10 \mathrm{~min}, 15,000 \mathrm{~J} / \mathrm{m}^{2}\end{array}$ & $\begin{array}{c}\text { Cardinal N95-ML (A) } \\
\text { 3M } 8210(\mathrm{C}) \\
\text { 3M } 1870(\mathrm{~F})\end{array}$ \\
\hline $\begin{array}{c}\text { Heimbuch, } \\
2011\end{array}$ & 254 & 80 & 15 & 18,000 & $1.6-2.2$ & 25 & Single UVGI arm & $\begin{array}{l}\text { N95 models }(n=3) \text { not } \\
\text { specified } \\
\text { SN95 models }(n=3) \text { not } \\
\text { specified }\end{array}$ \\
\hline Lin, $2018^{\mathrm{b}}$ & 254 & 6 & $1-20$ & $\begin{array}{l}11,340- \\
226,800\end{array}$ & 18.9 & 10 & $\begin{array}{c}\text { Arm 1: UVC } 245 \mathrm{~nm}, 1 \mathrm{~min}, 11,340 \\
\mathrm{~J} / \mathrm{m}^{2} \\
\text { Arm 2: UVC } 245 \mathrm{~nm}, 2 \mathrm{~min}, 22,680 \\
\mathrm{~J} / \mathrm{m}^{2} \\
\text { Arm 3: UVC } 245 \mathrm{~nm}, 5 \mathrm{~min}, 45,360 \\
\mathrm{~J} / \mathrm{m}^{2} \\
\text { Arm 4: UVC } 245 \mathrm{~nm}, 10 \mathrm{~min}, 113,400 \\
\mathrm{~J} / \mathrm{m}^{2} \\
\text { Arm 5: UVC } 245 \mathrm{~nm}, 20 \mathrm{~min}, 226,800 \\
\mathrm{~J} / \mathrm{m}^{2}\end{array}$ & $3 \mathrm{M} 8210$ \\
\hline Lore, 2012 & 254 & 15 & 15 & 18,000 & $1.6-2.2$ & 25 & Single UVGI arm & $\begin{array}{l}\text { 3M } 1860 \\
\text { 3M } 1870\end{array}$ \\
\hline
\end{tabular}




\begin{tabular}{|c|c|c|c|c|c|c|c|c|}
\hline $\begin{array}{c}\text { Author and } \\
\text { Year }\end{array}$ & $\begin{array}{l}\text { Wavelength } \\
(\mathbf{n m})\end{array}$ & $\begin{array}{c}\text { Watts } \\
(\mathbf{W})\end{array}$ & Duration (min) & $\begin{array}{c}\text { Dose } \\
\left(\mathrm{J} / \mathrm{m}^{2}\right)\end{array}$ & $\begin{array}{c}\text { Intensity } \\
\left(\mathrm{mW} / \mathrm{cm}^{2}\right)\end{array}$ & $\begin{array}{c}\text { Distance } \\
(\mathbf{c m})\end{array}$ & UVGI Study Arms & N95 Masks Evaluated \\
\hline Mills 2018 & 254 & NR & 1 & 1,000 & 0.39 & $100 \mathrm{~cm}$ & Single UVGI arm & $\begin{array}{c}\text { 3M 1860 } \\
\text { 3M 1870 } \\
\text { 3M VFlex 1805 } \\
\text { Alpha Protech 695 } \\
\text { Gerson 1730 Cup } \\
\text { Kimberly-ClarkPFR } \\
\text { Moldex 1512 Cup } \\
\text { Moldex 1712 Flat-fold } \\
\text { Moldex EZ-22 } \\
\text { Precept 65-3395 } \\
\text { Prestige Ameritech } \\
\text { RP88020 } \\
\text { Sperian HC-NB095 } \\
\text { Sperian HC-NB295F } \\
\text { U.S. Safety AD2N95A } \\
\text { U.S. Safety AD4N95 }\end{array}$ \\
\hline Vo 2009 & 254 & 40 & $60-300$ & $\begin{array}{c}14,400- \\
72,000\end{array}$ & 0.4 & NR & $\begin{array}{l}\text { Arm 1: } 1 \mathrm{hr}\left(14,400 \mathrm{~J} / \mathrm{m}^{2}\right) \\
\text { Arm 2: } 2 \mathrm{hr}\left(28,800 \mathrm{~J} / \mathrm{m}^{2}\right) \\
\text { Arm 3: } 3 \mathrm{hr}\left(43,200 \mathrm{~J} / \mathrm{m}^{2}\right) \\
\text { Arm 4: } 4 \mathrm{hr}\left(57,600 \mathrm{~J} / \mathrm{m}^{2}\right) \\
\text { Arm 5: } 5 \mathrm{hr}\left(72,000 \mathrm{~J} / \mathrm{m}^{2}\right)\end{array}$ & N1105 \\
\hline Woo 2012 & 254 & 4 & $15-120$ & $\begin{array}{l}9,000- \\
72,000\end{array}$ & 1.0 & 10 & $\begin{array}{l}\text { Arm 1: } 15 \mathrm{~min}, 9,000 \mathrm{~J} / \mathrm{m}^{2} \\
\text { Arm 2: } 30 \mathrm{~min}, 18,000 \mathrm{~J} / \mathrm{m}^{2} \\
\text { Arm 3: } 60 \mathrm{~min}, 36,000 \mathrm{~J} / \mathrm{m}^{2} \\
\text { Arm 4: } 120 \mathrm{~min}, 72,000 \mathrm{~J} / \mathrm{m}^{2}\end{array}$ & $3 \mathrm{M} 1870$ \\
\hline
\end{tabular}

aFisher et al evaluated 22 different UVGI protocols and 6 different masks, however, germicidal results were only reported for 9 arms and 3 masks

${ }^{b}$ Lin et al also evaluated 5 UVGI arms using 365 nm UV-A light. 
Table V: Log reduction in viral pathogens following ultraviolet germicidal irradiation in water and non-water mediums

\begin{tabular}{|c|c|c|c|c|c|c|c|}
\hline $\begin{array}{l}\text { Author, } \\
\text { Year }\end{array}$ & Viral Pathogen & $\begin{array}{c}\text { Cumulative Dose } \\
\qquad\left(\mathbf{J} / \mathbf{m}^{2}\right)\end{array}$ & Medium & Medium Description & $\begin{array}{c}\text { Average } \\
\text { number of } \\
\text { measurements }\end{array}$ & Log Change & $\begin{array}{c}\text { Standard } \\
\text { Error (SE) }\end{array}$ \\
\hline \multicolumn{8}{|c|}{ Cumulative Dose $<20,000 \mathrm{~J} / \mathrm{m}^{2}$} \\
\hline Fisher 2010 & MS2 & 1,500 & Water & Water & 4 & 1.88 & 0.20 \\
\hline Fisher 2010 & MS2 & 3,000 & Water & Water & 4 & 2.75 & 0.30 \\
\hline Fisher 2010 & MS2 & 6,000 & Water & Water & 4 & 3.35 & 0.35 \\
\hline Woo 2012 & MS2 & 9,000 & Water & Water & 3 & 3.07 & 0.42 \\
\hline Mills 2018 & H1N1 & 10,000 & Not water & AS & 3 & 3.71 & 0.24 \\
\hline Mills 2018 & $\mathrm{H} 1 \mathrm{~N} 1$ & 10,000 & Not water & Sebum & 3 & 3.51 & 0.35 \\
\hline Vo 2009 & MS2 & 14,400 & Water & 271B & 3 & 1.83 & 0.31 \\
\hline Fisher 2010 & MS2 & 15,000 & Water & Water & 4 & 3.85 & 0.26 \\
\hline $\begin{array}{l}\text { Heimbuch } \\
2011\end{array}$ & H1N1 & 18,000 & Water & Water & 3 & 4.81 & 0.45 \\
\hline Lore 2012 & H5N1 & 18,000 & Water & Water & 9 & 4.60 & 0.21 \\
\hline Woo 2012 & $\mathrm{MS} 2$ & 18,000 & Water & Water & 3 & 4.04 & 0.40 \\
\hline Woo 2012 & MS2 & 18,000 & Not water & AS $(0.6 \%)$ & 3 & 1.50 & 0.32 \\
\hline Woo 2012 & MS2 & 18,000 & Not water & $\mathrm{BE}(0.6 \%)$ & 3 & 1.35 & 0.31 \\
\hline Woo 2012 & MS2 & 18,000 & Not water & $\begin{array}{c}\text { Mucin-free AS }(0.6 \% \& \\
0.3 \%)\end{array}$ & 3 & 3.76 & 0.30 \\
\hline Woo 2012 & MS2 & 18,000 & Not water & $\begin{array}{c}0.3 \% \text { Salt-free AS }(0.3 \% \\
\text { mucin medium })\end{array}$ & 3 & 3.12 & 0.31 \\
\hline \multicolumn{8}{|c|}{ Cumulative Dose $>20,000 \mathrm{~J} / \mathrm{m}^{2}$} \\
\hline Vo 2009 & MS2 & 28,800 & Water & 271B & 3 & 2.64 & 0.31 \\
\hline Woo 2012 & MS2 & 36,000 & Water & Water & 3 & 4.67 & 0.17 \\
\hline Woo 2012 & MS2 & 36,000 & Not water & AS $(0.6 \%)$ & 3 & 2.50 & 0.35 \\
\hline Woo 2012 & MS2 & 36,000 & Not water & $\mathrm{BE}(0.3 \%)$ & 3 & 2.15 & 0.31 \\
\hline Woo 2012 & $\mathrm{MS} 2$ & 36,000 & Not water & Mucin-free AS $(0.3 \%)$ & 3 & 4.33 & 0.21 \\
\hline Woo 2012 & MS2 & 36,000 & Not water & Mucin-free AS $(0.6 \%)$ & 3 & 4.42 & 0.31 \\
\hline Woo 2012 & MS2 & 36,000 & Not water & $\begin{array}{c}0.3 \% \text { Salt-free AS }(0.3 \% \\
\text { mucin medium })\end{array}$ & 3 & 3.54 & 0.34 \\
\hline
\end{tabular}




\begin{tabular}{|c|c|c|c|c|c|c|c|}
\hline \multicolumn{8}{|c|}{ Cumulative Dose $>40,000 \mathrm{~J} / \mathrm{m}^{2}$} \\
\hline Vo 2009 & MS2 & 43,200 & Water & 271B & 3 & 3.00 & 0.31 \\
\hline Vo 2009 & MS2 & 57,600 & Water & $271 \mathrm{~B}$ & 3 & 3.16 & 0.31 \\
\hline Vo 2009 & MS2 & 72,000 & Water & 271B & 3 & 3.76 & 0.31 \\
\hline Woo 2012 & MS2 & 72,000 & Not water & AS $(0.6 \%)$ & 3 & 3.28 & 0.37 \\
\hline Woo 2012 & MS2 & 72,000 & Not water & $\mathrm{BE}(0.3 \%)$ & 3 & 2.34 & 0.30 \\
\hline Woo 2012 & MS2 & 72,000 & Not water & Mucin-free AS $(0.3 \%)$ & 3 & 4.94 & 0.14 \\
\hline Woo 2012 & MS2 & 72,000 & Not water & Mucin-free AS $(0.6 \%)$ & 3 & 5.08 & 0.31 \\
\hline Woo 2012 & MS2 & 72,000 & Not water & $\begin{array}{c}0.3 \% \text { Salt-free AS }(0.3 \% \\
\text { mucin medium })\end{array}$ & 3 & 4.37 & 0.11 \\
\hline
\end{tabular}

Abbreviations: AS - artificial saliva; $\mathrm{BE}$ - beef extract 
Appendix A - PRISMA Checklist

\begin{tabular}{|c|c|c|c|}
\hline Section/topic & \# & Checklist item & $\begin{array}{l}\text { Reported } \\
\text { on page \# }\end{array}$ \\
\hline \multicolumn{4}{|l|}{ TITLE } \\
\hline Title & 1 & Identify the report as a systematic review, meta-analysis, or both. & 1 \\
\hline \multicolumn{4}{|l|}{ ABSTRACT } \\
\hline Structured summary & 2 & $\begin{array}{l}\text { Provide a structured summary including, as applicable: background; objectives; data sources; } \\
\text { study eligibility criteria, participants, and interventions; study appraisal and synthesis methods; } \\
\text { results; limitations; conclusions and implications of key findings; systematic review registration } \\
\text { number. }\end{array}$ & 3 \\
\hline \multicolumn{4}{|l|}{ INTRODUCTION } \\
\hline Rationale & 3 & Describe the rationale for the review in the context of what is already known. & 5 \\
\hline Objectives & 4 & $\begin{array}{l}\text { Provide an explicit statement of questions being addressed with reference to participants, } \\
\text { interventions, comparisons, outcomes, and study design (PICOS). }\end{array}$ & 6 \\
\hline \multicolumn{4}{|l|}{ METHODS } \\
\hline Protocol and registration & 5 & $\begin{array}{l}\text { Indicate if a review protocol exists, if and where it can be accessed (e.g., Web address), and, if } \\
\text { available, provide registration information including registration number. }\end{array}$ & 6 \\
\hline Eligibility criteria & 6 & $\begin{array}{l}\text { Specify study characteristics (e.g., PICOS, length of follow-up) and report characteristics (e.g., } \\
\text { years considered, language, publication status) used as criteria for eligibility, giving rationale. }\end{array}$ & $6-7$ \\
\hline Information sources & 7 & $\begin{array}{l}\text { Describe all information sources (e.g., databases with dates of coverage, contact with study } \\
\text { authors to identify additional studies) in the search and date last searched. }\end{array}$ & $7-8$ \\
\hline Search & 8 & $\begin{array}{l}\text { Present full electronic search strategy for at least one database, including any limits used, such } \\
\text { that it could be repeated. }\end{array}$ & $\begin{array}{l}\text { Appendix } \\
\text { B }\end{array}$ \\
\hline Study selection & 9 & $\begin{array}{l}\text { State the process for selecting studies (i.e., screening, eligibility, included in systematic review, } \\
\text { and, if applicable, included in the meta-analysis). }\end{array}$ & 8 \\
\hline Data collection process & 10 & $\begin{array}{l}\text { Describe method of data extraction from reports (e.g., piloted forms, independently, in duplicate) } \\
\text { and any processes for obtaining and confirming data from investigators. }\end{array}$ & $8-9$ \\
\hline Data items & 11 & $\begin{array}{l}\text { List and define all variables for which data were sought (e.g., PICOS, funding sources) and any } \\
\text { assumptions and simplifications made. }\end{array}$ & $8-9$ \\
\hline
\end{tabular}




\begin{tabular}{|c|c|c|c|}
\hline $\begin{array}{l}\text { Risk of bias in individual } \\
\text { studies }\end{array}$ & 12 & $\begin{array}{l}\text { Describe methods used for assessing risk of bias of individual studies (including specification of } \\
\text { whether this was done at the study or outcome level), and how this information is to be used in } \\
\text { any data synthesis. }\end{array}$ & 10 \\
\hline Summary measures & 13 & State the principal summary measures (e.g., risk ratio, difference in means). & 9 \\
\hline Synthesis of results & 14 & $\begin{array}{l}\text { Describe the methods of handling data and combining results of studies, if done, including } \\
\left.\text { measures of consistency (e.g., }\left.\right|^{2}\right) \text { for each meta-analysis. }\end{array}$ & $9-10$ \\
\hline $\begin{array}{l}\text { Risk of bias across } \\
\text { studies }\end{array}$ & 15 & $\begin{array}{l}\text { Specify any assessment of risk of bias that may affect the cumulative evidence (e.g., publication } \\
\text { bias, selective reporting within studies). }\end{array}$ & 10 \\
\hline Additional analyses & 16 & $\begin{array}{l}\text { Describe methods of additional analyses (e.g., sensitivity or subgroup analyses, meta- } \\
\text { regression), if done, indicating which were pre-specified. }\end{array}$ & $\begin{array}{l}\text { described } \\
\text { in the } \\
\text { protocol }\end{array}$ \\
\hline \multicolumn{4}{|l|}{ RESULTS } \\
\hline Study selection & 17 & $\begin{array}{l}\text { Give numbers of studies screened, assessed for eligibility, and included in the review, with } \\
\text { reasons for exclusions at each stage, ideally with a flow diagram. }\end{array}$ & $\begin{array}{l}39, \text { Figure } \\
1\end{array}$ \\
\hline Study characteristics & 18 & $\begin{array}{l}\text { For each study, present characteristics for which data were extracted (e.g., study size, PICOS, } \\
\text { follow-up period) and provide the citations. }\end{array}$ & Table 1 \\
\hline $\begin{array}{l}\text { Risk of bias within } \\
\text { studies }\end{array}$ & 19 & $\begin{array}{l}\text { Present data on risk of bias of each study and, if available, any outcome level assessment (see } \\
\text { item 12). }\end{array}$ & $\begin{array}{l}\text { Appendix } \\
\text { D }\end{array}$ \\
\hline $\begin{array}{l}\text { Results of individual } \\
\text { studies }\end{array}$ & 20 & $\begin{array}{l}\text { For all outcomes considered (benefits or harms), present, for each study: (a) simple summary } \\
\text { data for each intervention group (b) effect estimates and confidence intervals, ideally with a forest } \\
\text { plot. }\end{array}$ & $\begin{array}{l}\text { Figure } 2 \\
\text { Figure } 3\end{array}$ \\
\hline Synthesis of results & 21 & $\begin{array}{l}\text { Present results of each meta-analysis done, including confidence intervals and measures of } \\
\text { consistency. }\end{array}$ & $12-14$ \\
\hline $\begin{array}{l}\text { Risk of bias across } \\
\text { studies }\end{array}$ & 22 & Present results of any assessment of risk of bias across studies (see Item 15). & 15 \\
\hline Additional analysis & 23 & $\begin{array}{l}\text { Give results of additional analyses, if done (e.g., sensitivity or subgroup analyses, meta- } \\
\text { regression [see Item 16]). }\end{array}$ & $\mathrm{n} / \mathrm{a}$ \\
\hline \multicolumn{4}{|l|}{ DISCUSSION } \\
\hline Summary of evidence & 24 & $\begin{array}{l}\text { Summarize the main findings including the strength of evidence for each main outcome; consider } \\
\text { their relevance to key groups (e.g., healthcare providers, users, and policy makers). }\end{array}$ & $18-20$ \\
\hline
\end{tabular}




\begin{tabular}{|l|c|l|l|}
\hline Limitations & 25 & $\begin{array}{l}\text { Discuss limitations at study and outcome level (e.g., risk of bias), and at review-level (e.g., } \\
\text { incomplete retrieval of identified research, reporting bias). }\end{array}$ & 20 \\
\hline Conclusions & 26 & $\begin{array}{l}\text { Provide a general interpretation of the results in the context of other evidence, and implications } \\
\text { for future research. }\end{array}$ & $20-21$ \\
\hline \hline FUNDING & 27 & $\begin{array}{l}\text { Describe sources of funding for the systematic review and other support (e.g., supply of data); } \\
\text { role of funders for the systematic review. }\end{array}$ & 23 \\
\hline Funding
\end{tabular}

From: Moher D, Liberati A, Tetzlaff J, Altman DG, The PRISMA Group (2009). Preferred Reporting Items for Systematic Reviews and Meta-Analyses: The PRISMA Statement. PLoS Med 6(6): e1000097. doi:10.1371/journal.pmed1000097

For more information, visit: www.prisma-statement.org.

Page 2 of 2 


\section{Appendix B - Search Strategy}

\section{Medline}

1. Ultraviolet Rays/

2. Decontamination/

3. ((ultraviolet or ultra violet or UV or actinic) adj3 (ray or rays or radiation or irradiation or decontaminat* or light)).tw,kf.

4. UVGI.tw,kf.

5. or/1-4

6. Masks/

7. Respiratory Protective Devices/

8. Personal Protective Equipment/

9. (mask or masks or facemask or facemasks).tw, kf.

10. (fabrication or manufacturing).ti.

11. 9 not 10

12. (filtering adj3 (facepiece or face piece or facepieces or face pieces)).tw,kf.

13. (face adj2 shield*).tw,kf.

14. (N95 or N 95).tw,kf.

15. (ffr or ffrs).tw,kf.

16. or/6-8,11-15

17.5 and 16

\section{Embase}

1. ultraviolet radiation/

2. decontamination/

3. ((ultraviolet or ultra violet or UV or actinic) adj3 (ray or rays or radiation or irradiation or decontaminat* or light)).tw,kw.

4. UVGI.tw,kw.

5. or/1-4

6. exp face mask/

7. surgical mask/

8. gas mask/

9. protective equipment/

10. (mask or masks or facemask or facemasks).tw,kw.

11. (fabrication or manufacturing).ti.

12. 10 not 11

13. (filtering adj3 (facepiece or face piece or facepieces or face pieces)).tw,kw.

14. (face adj2 shield*).tw,kw.

15. (N95 or N 95).tw,kw.

16. (ffr or ffrs).tw,kw.

17. or/6-9,12-16

18.5 and 17 


\section{Global Health}

All fields search:

((ultraviolet or "ultra violet" or UV or UVGI or "germicidal irradiation" or decontaminate or decontamination) AND ("respiratory protective device*" or mask* or "face shield*" or faceshield* or $\mathrm{n} 95$ or $\mathrm{n}-95$ or ffr or ffrs or "filtering face*"))

\section{Google Scholar through Publish and Perish}

(ultraviolet|ultra violet|UV|UVGI|germicidal

irradiation|decontaminate|decontamination)(respiratory protective device*|mask ${ }^{*} \mid$ face

shield*|n95|n-95|ffr|ffrs|filtering face*)

\section{WHO database}

The entire record set of March 23, 2020 was downloaded from

https://www.who.int/emergencies/diseases/novel-coronavirus-2019/global-research-on-novelcoronavirus-2019-ncov into Reference Manager and then all indexed and non-indexed fields were searched using these query strings:

Ultraviolet $\}$ or $\{$ ultra violet $\}$ or $\{$ ultra-violet $\}$ or $\{\mathrm{UV}\}$ or $\{\mathrm{UVGI}\}$ or $\{$ germicidal irradiation $\}$ or $\{$ decontamin*\}

AND

$\{$ respiratory protective device* $\}$ or $\left\{\operatorname{mask}^{*}\right\}$ or $\{$ face shield* $\}$ or $\{n 95\}$ or $\{n-95\}$ or [32] or $\{$ ffrs $\}$ or $\left\{\right.$ filtering face* $\left.{ }^{*}\right\}$ 


\section{Appendix C: Assessment of fit and physical appearance of N95 FFRs following UVGI exposure}

\section{Table C.1- Physical Appearance and Odor}

\begin{tabular}{|c|c|c|c|c|}
\hline $\begin{array}{l}\text { Author, } \\
\text { Year }\end{array}$ & UVGI Intervention & N95 Masks & $\begin{array}{c}\text { Method of Assessment in } \\
\text { Change in Physical Appearance } \\
\text { or Odor }\end{array}$ & $\begin{array}{c}\text { Changes following UVGI } \\
\text { Exposure }\end{array}$ \\
\hline $\begin{array}{l}\text { Bergman, } \\
2010\end{array}$ & $\begin{array}{l}\text { Wavelength }(\mathrm{nm}): 254 \\
\text { Watts }(\mathrm{W}): 40 \\
\text { Duration }(\mathrm{min}): 45 \\
\text { Dose }\left(\mathrm{J} / \mathrm{m}^{2}\right): 48,600 \\
\text { Intensity }\left(\mathrm{mW} / \mathrm{cm}^{2}\right): 1.8 \\
\text { Distance }(\mathrm{cm}): 25\end{array}$ & $\begin{array}{l}\text { N95-A } \\
\text { N95-B } \\
\text { N95-C } \\
\text { SN95-D } \\
\text { SN95-E } \\
\text { SN95-F }\end{array}$ & $\begin{array}{l}\text { Visual inspection for changes in } \\
\text { physical appearance } \\
\text { Changes in odor by sniffing the } \\
\text { mask }\end{array}$ & $\begin{array}{l}\text { No significant changes } \\
\text { No significant changes }\end{array}$ \\
\hline $\begin{array}{l}\text { Bergman, } \\
2011\end{array}$ & $\begin{array}{l}\text { Wavelength }(\mathrm{nm}): 245 \\
\text { Watts }(\mathrm{W}): 40 \\
\text { Duration }(\mathrm{min}): 15 \\
\text { Dose }\left(\mathrm{J} / \mathrm{m}^{2}\right): 16,200 \\
\text { Intensity }\left(\mathrm{mW} / \mathrm{cm}^{2}\right): 1.8 \\
\text { Distance }(\mathrm{cm}): \mathrm{NR}\end{array}$ & $\begin{array}{l}\text { 3M } 1860 \\
\text { 3M } 1870 \\
\text { KC PFR95-270 (46767) }\end{array}$ & $\begin{array}{l}\text { Visual inspection for changes in } \\
\text { physical appearance }\end{array}$ & No significant changes \\
\hline $\begin{array}{l}\text { Heimbuch, } \\
2011\end{array}$ & $\begin{array}{l}\text { Wavelength }(\mathrm{nm}): 254 \\
\text { Watts }(\mathrm{W}): 80 \\
\text { Duration }(\mathrm{min}): 15 \\
\text { Dose }\left(\mathrm{J} / \mathrm{m}^{2}\right): 14,400-59,400 \\
\text { Intensity }\left(\mathrm{mW} / \mathrm{cm}^{2}\right): 1.6-2.2 \\
\text { Distance }(\mathrm{cm}): 25\end{array}$ & $\begin{array}{l}\text { N95 models }(n=3) \text { not specified } \\
\text { SN95 models }(n=3) \text { not } \\
\text { specified }\end{array}$ & $\begin{array}{l}\text { Visual inspection for changes in } \\
\text { physical appearance }\end{array}$ & No significant changes \\
\hline $\begin{array}{l}\text { Viscusi, } \\
2007\end{array}$ & $\begin{array}{l}\text { Wavelength }(\mathrm{nm}): 254 \\
\text { Watts }(\mathrm{W}): 40 \\
\text { Duration }(\mathrm{min}): 30-480 \\
\text { Dose }(\mathrm{J} / \mathrm{m} 2): \mathrm{NR} \\
\text { Intensity }(\mathrm{mW} / \mathrm{cm} 2): \mathrm{NR} \\
\text { Distance }(\mathrm{cm}): \mathrm{NR}\end{array}$ & $\begin{array}{l}\text { N95 model }(\mathrm{n}=1) \text { not } \\
\text { specified }\end{array}$ & Visual inspection & No significant changes \\
\hline $\begin{array}{l}\text { Viscusi, } \\
2011\end{array}$ & $\begin{array}{l}\text { Wavelength }(\mathrm{nm}): 245 \\
\text { Watts }(\mathrm{W}): 40 \\
\text { Duration }(\mathrm{min}): 30 \\
\text { Dose }\left(\mathrm{J} / \mathrm{m}^{2}\right): 32,400 \\
\text { Intensity }\left(\mathrm{mW} / \mathrm{cm}^{2}\right): 1.8 \\
\text { Distance }(\mathrm{cm}): \mathrm{NR}\end{array}$ & $\begin{array}{l}\text { 3M } 8000 \\
\text { 3M } 8210 \\
\text { Moldex } 2200 \\
\text { 3M1860 } \\
\text { 3M1870 } \\
\text { Kimberly Clark PFR95-270 }\end{array}$ & $\begin{array}{l}\text { Visual inspection for changes in } \\
\text { physical appearance } \\
\text { Changes in subjects perception of } \\
\text { odor strength using a Visual } \\
\text { Analog Scale }\end{array}$ & $\begin{array}{l}\text { No significant changes } \\
\text { No significant changes }\end{array}$ \\
\hline & & & Changes in odor by sniffing the & No significant changes \\
\hline
\end{tabular}




\begin{tabular}{|c|c|c|c|c|}
\hline & & & mask & \\
\hline \multirow{7}{*}{$\begin{array}{l}\text { Viscusi, } \\
2009\end{array}$} & Wavelength (nm): 254 & N95-A & Visual inspection for changes in & No significant changes \\
\hline & Watts (W): 40 & N95-B & physical appearance & \\
\hline & Duration (min): 30 & N95-C & & \\
\hline & Dose $\left(\mathrm{J} / \mathrm{m}^{2}\right): 3,520-3,620$ & SN95-D & Changes in odor by sniffing the & No significant changes \\
\hline & Intensity $\left(\mathrm{mW} / \mathrm{cm}^{2}\right): 0.18$ to 0.20 & SN95-E & mask & \\
\hline & Distance $(\mathrm{cm}): \mathrm{NR}$ & SN95-F & & \\
\hline & & & $\begin{array}{l}\text { Manual inspection for changes in } \\
\text { 'feel' of the respirator (softness, } \\
\text { pliability, coarseness, roughness, } \\
\text { etc.). }\end{array}$ & No significant changes \\
\hline
\end{tabular}

Abbreviations: UVGI - Ultraviolet germicidal irradiation

Table C.2 - Fit

\begin{tabular}{|c|c|c|c|c|}
\hline $\begin{array}{l}\text { Author, } \\
\text { Year }\end{array}$ & UVGI Intervention & N95 Masks & $\begin{array}{l}\text { Method of Assessment of } \\
\text { Changes in Fit }\end{array}$ & $\begin{array}{l}\text { Changes following UVGI } \\
\text { Exposure }\end{array}$ \\
\hline $\begin{array}{l}\text { Viscusi, } \\
2011\end{array}$ & $\begin{array}{l}\text { Wavelength }(\mathrm{nm}): 245 \\
\text { Watts }(\mathrm{W}): 40 \\
\text { Duration }(\mathrm{min}): 30 \\
\text { Dose }\left(\mathrm{J} / \mathrm{m}^{2}\right): 32,400 \\
\text { Intensity }\left(\mathrm{mW} / \mathrm{cm}^{2}\right): 1.8 \\
\text { Distance }(\mathrm{cm}): \mathrm{NR}\end{array}$ & $\begin{array}{l}\text { 3M } 8000 \\
\text { 3M } 8210 \\
\text { Moldex } 2200 \\
\text { 3M } 1860 \\
\text { 3M } 1870 \\
\text { Kimberly Clark PFR95-270 }\end{array}$ & $\begin{array}{l}\text { Pre-UVGI Exposure: Standard } \\
\text { eight exercise OSHA fit test } \\
\text { protocol } \\
\text { Post-UVGI Exposure: Multiple } \\
\text { donning protocol using five } \\
\text { exercises from the OHSA fit test } \\
\text { protocol plus a final standard } \\
\text { breathing exercise. The test } \\
\text { subject repeated fit testing with } \\
\text { the same FFR until accomplishing } \\
\text { all five donnings without a strap } \\
\text { breakage. Subjects repeated any } \\
\text { test with a strap break, starting } \\
\text { with a new FFR. }\end{array}$ & No significant reductions in fit \\
\hline $\begin{array}{l}\text { Bergman, } \\
2011\end{array}$ & $\begin{array}{l}\text { Wavelength }(\mathrm{nm}): 245 \\
\text { Watts }(\mathrm{W}): 40 \\
\text { Duration }(\mathrm{min}): 15 \\
\text { Dose }\left(\mathrm{J} / \mathrm{m}^{2}\right): 16,200 \\
\text { Intensity }\left(\mathrm{mW} / \mathrm{cm}^{2}\right): 1.8 \\
\text { Distance }(\mathrm{cm}): \mathrm{NR}\end{array}$ & $\begin{array}{l}\text { 3M } 1860 \\
\text { 3M } 1870 \\
\text { KC PFR95-270 (46767) }\end{array}$ & $\begin{array}{l}\text { Pre-UVGI Exposure: Standard } \\
\text { eight exercise OHSA fit test } \\
\text { protocol } \\
\text { Post-UVGI Exposure: Multiple } \\
\text { donning fit testing using a } \\
\text { shortened } 121 \mathrm{sec}\end{array}$ & $\begin{array}{l}\text { Three cycles of UVGI did not } \\
\text { cause significant changes in mask } \\
\text { fit. } \\
\text { The passing rate for the } 3 \mathrm{M} 1860 \\
\text { was } 95 \%, 100 \% \text { and } 100 \% \text { after } \\
1,2 \text { and } 3 \text { cycles respectively. }\end{array}$ \\
\hline
\end{tabular}


PORTACOUNT protocol. The

test used 6 exercises for 10

seconds each. Fit Factor was

calculated as the ratio of the

ambient particle concentration

(sampled for $15 \mathrm{sec}$ ) divided by

the mask concentration (sampled

for $81 \mathrm{sec})$.
The passing rate for the $3 \mathrm{M} 1870$

was $100 \%$ after 1,2 and 3 cycles.

The passing rate for the $\mathrm{KC}$

PFR95-270 (46767) was 95\%,

$95 \%$ and $90 \%$ after 1,2 and 3

cycles.

Abbreviations: FFR - filtering facemask respirator; OHSA - Occupational Safety and Health Administration; UVGI - Ultraviolet germicidal irradiation 


\begin{tabular}{|c|c|c|c|c|}
\hline $\begin{array}{l}\text { Author, } \\
\text { Year }\end{array}$ & $\begin{array}{l}\text { Population: Masks evaluated } \\
\text { from same lot to minimize } \\
\text { any lot-to-lot variation }\end{array}$ & $\begin{array}{l}\text { Design: Controlled } \\
\text { study or pre-post } \\
\text { design }\end{array}$ & $\begin{array}{l}\text { Methodology: All evaluations } \\
\text { performed in the same lab } \\
\text { conditions }\end{array}$ & $\begin{array}{c}\text { Outcome: evaluators blinded to study arm } \\
\text { or outcome evaluated objectively (result } \\
\text { provided by a machine) }\end{array}$ \\
\hline $\begin{array}{l}\text { Bergman, } \\
2010\end{array}$ & Yes & Yes & Not reported & $\begin{array}{l}\text { Aerosol Penetration: Objective evaluation } \\
\text { Airflow Resistance: Objective evaluation } \\
\text { Physical Appearance: No }\end{array}$ \\
\hline $\begin{array}{l}\text { Bergman, } \\
2011\end{array}$ & Yes & Yes & Yes & $\begin{array}{l}\text { Fit Testing: Objective evaluation } \\
\text { Physical Appearance: No }\end{array}$ \\
\hline Fisher, 2010 & Not reported & Yes & Not reported & Decontamination: No \\
\hline $\begin{array}{l}\text { Heimbuch, } \\
2011\end{array}$ & Not reported & Yes & $\begin{array}{l}\text { Similar conditions reported during } \\
\text { the contamination process. } \\
\text { Conditions during outcome } \\
\text { measurement were not reported }\end{array}$ & $\begin{array}{l}\text { Decontamination: No } \\
\text { Physical Appearance: No }\end{array}$ \\
\hline Lin, 2018 & Not reported & Yes & Yes & Decontamination: No \\
\hline $\begin{array}{l}\text { Lindsley, } \\
2015\end{array}$ & Yes & Yes & Not reported & $\begin{array}{l}\text { Aerosol Penetration: Objective evaluation } \\
\text { Airflow Resistance: Objective evaluation }\end{array}$ \\
\hline Lore, 2012 & Not reported & Yes & $\begin{array}{l}\text { Similar conditions reported during } \\
\text { the contamination process. } \\
\text { Conditions during outcome } \\
\text { measurement were not reported }\end{array}$ & $\begin{array}{l}\text { Aerosol Penetration: Objective evaluation } \\
\text { Decontamination: No }\end{array}$ \\
\hline Mills, 2018 & Not reported & Yes & Yes & Decontamination: No \\
\hline $\begin{array}{l}\text { Viscusi, } \\
2007\end{array}$ & Yes & Yes & Yes & $\begin{array}{l}\text { Aerosol penetration: Objective evaluation } \\
\text { Physical Appearance: Objective evaluation }\end{array}$ \\
\hline $\begin{array}{l}\text { Viscusi, } \\
2009\end{array}$ & Yes & Yes & Yes & $\begin{array}{l}\text { Aerosol Penetration: Objective evaluation } \\
\text { Airflow Resistance: Objective evaluation } \\
\text { Physical Appearance: No }\end{array}$ \\
\hline $\begin{array}{l}\text { Viscusi, } \\
2011\end{array}$ & Yes & Yes & Yes & $\begin{array}{l}\text { Physical Appearance: No } \\
\text { Fit: Subjects participating in the fit test were } \\
\text { blinded, outcome assessors were not }\end{array}$ \\
\hline
\end{tabular}




\begin{tabular}{ccccc}
\hline Vo, 2009 & Not reported & Yes & Not reported & Decontamination: No \\
\hline Woo, 2012 & Not reported & Yes & Yes & Decontamination: No \\
\hline
\end{tabular}

Abbreviations: UVGI - Ultraviolet germicidal irradiation 